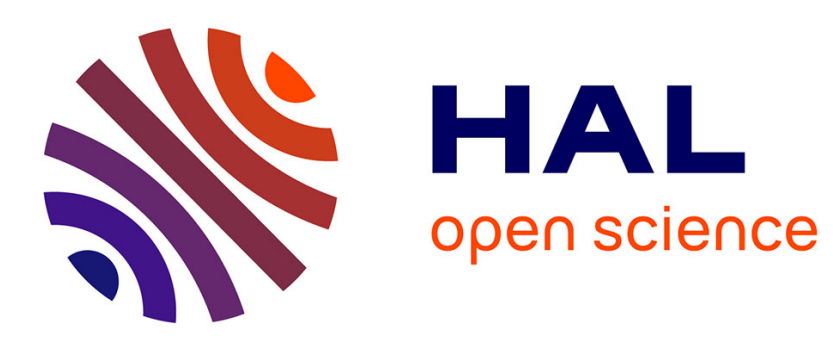

\title{
Trade liberalization and institutional reforms
}

Angela Cheptea

\section{To cite this version:}

Angela Cheptea. Trade liberalization and institutional reforms. Economics of Transition, 2007, 15

(2), pp.211-255. 10.1111/j.1468-0351.2007.00286.x . hal-02360551

\section{HAL Id: hal-02360551 \\ https://hal.science/hal-02360551}

Submitted on 12 Nov 2019

HAL is a multi-disciplinary open access archive for the deposit and dissemination of scientific research documents, whether they are published or not. The documents may come from teaching and research institutions in France or abroad, or from public or private research centers.
L'archive ouverte pluridisciplinaire HAL, est destinée au dépôt et à la diffusion de documents scientifiques de niveau recherche, publiés ou non, émanant des établissements d'enseignement et de recherche français ou étrangers, des laboratoires publics ou privés. 


\section{Trade liberalization and institutional reforms ${ }^{1}$}

\section{Angela Cheptea}

INRA, UR122 Economie et Sociologie Rurales, 4 Allée Adolphe Bobièrre, CS61103, Rennes, France. E-mail: Angela.Cheptea@rennes.inra.fr

\section{Abstract}

The accession of Central and Eastern European (CEE) countries to the European Union (EU) is expected to lead to the new member countries becoming more like the older members, including in terms of trade. In this paper, we focus on two factors promoting CEE-EU trade integration: trade liberalization and institutional reforms. Measures of trade liberalization undertaken by both parties during the 1990s were very substantial, but did not always produce the expected upsurge of regional trade flows. Much less progress has been made in improving the functioning of CEE institutions (e.g., progress in the privatization process or in reducing corruption). Countries where most important changes at the institutional level occurred were also those that most increased their trade with the EU. Comparing the impact of these two factors, we find that improving institutions in CEE countries can generate as much trade as the removal of all tariff and non-tariff barriers. The paper also addresses the issue of the presence of reversed causality between trade and institutions, and the pro-trade effect of institutional similarity.

JEL classifications: F12, F13, F15, O17, P30.

Keywords: Trade liberalization, institutions, trade creation, Central and Eastern Europe.

\footnotetext{
${ }^{1}$ I am grateful to Thierry Mayer for valuable insights and numerous discussions. I have benefited from helpful comments from Maitreesh Ghatak, James Harrigan, Richard Kneller, and two anonymous referees. I thank Soledad Zignago for her help with extraction and processing of data. This paper was written during my stay at TEAM, University of Paris I. Financial support from the University of Paris I and the University of Paris XI is gratefully acknowledged.
} 


\section{Introduction}

East-West European trade integration started with the reduction of tariffs on bilateral imports, which generated an important increase in regional trade. However, even after most policy barriers have been eliminated, the potential for further expansion of trade remains large. This suggests that the reduction of other types of impediments to European trade is possible. It confirms at the same time the existence of complementary determinants of trade, less explored in the literature, but no less important in shaping trade patterns. Another factor was subject to important changes during the same time period: institutions in transition countries. The abandoning of the centralized system by these countries, and their increasing willingness to join the EU motivated their governments to undertake large reforms in this area. Institutional reforms were a chief condition imposed by the EU on new candidate countries. In order to permit the good functioning of the enlarged union, candidate states were required to adopt changes in their legislation, increase the efficiency of the judicial system, reduce corruption, and so on. However, unlike in the case of trade policy, progress made by different countries in this direction was more moderate, and varied significantly across countries. The present paper explores the institutional heterogeneity and regional trade liberalization in Europe, and develops specific recommendations in terms of economic policy for further trade integration.

The focus on institutions is well established in some areas of economics, such as the new institutional economics (Coase, 1937; North, 1990; Williamson, 2000), and growth and development economics (Acemoglu et al., 2001; Rodrik et al., 2002; Kaufmann et al., 2003). However, only very recently have institutions captured the interest of international trade economists. Institutions are generally defined as formal and informal rules of behaviour, means for ensuring their application, mediation procedures in case of dispute, sanctions for violation of established rules, and organizations and bodies charged with their enforcement. The quality of institutions is judged as more or less good according to the more or less good functioning of their different elements. Examples include constitutions, judicial systems, banks, corporate and bankruptcy laws, tax collection and competition agencies. Effective institutions are those which ensure that the incentives they create actually lead to the desired behaviour.

Recent work by Anderson and Marcouiller (2002), de Groot et al. (2004), Jansen and Nordas (2004), Koukhartchouk and Maurel (2003), and Duc et al. (2005) illustrate the pro-trade effect of institutions. However, this literature disregards the possibility of institutions being affected by a country's participation in international trade. Inspired by the research in economic development, the present paper studies the endogeneity between trade and institutions. We use a monopolistic competition model of trade to analyse the relationship between trade and the quality of domestic and foreign institutions for 25 European countries. Better institutions at home and abroad increase the security of international exchange, 
reduce uncertainty and contract enforcement costs, and thereby persuade firms to trade more. Conversely, increased participation in international transactions generates more demand for institutional reforms, and puts higher pressure on the government to finance and execute them. Trade is, thus, a channel through which a country's economic agents can learn new ways to ameliorate existing institutions. Although the existing literature establishes that fragmentation of institutions at country level is an additional source of transaction costs, a specific variable measuring institutional heterogeneity is missing. In this paper, we introduce the concept of institutional distance to fill this gap. Even in the case of well-functioning institutions, the existence of country-specific procedures and practices introduces confusion and supplementary costs. Therefore, similarity between institutional frameworks in the exporting and importing countries, along with the development of high-quality national institutions, has a trade creating effect.

The effect of institutional reforms on trade is compared to that of foreign trade policy. We compute the share of each factor in total border-specific trade costs, and find strong national institutions to be no less important for promoting European trade than the removal of policy barriers. A further increase of regional trade is, therefore, likely to occur even after all tariff and non-tariff barriers have been eliminated. The separation of institutions into general, and specific to transition countries, and the employment of quantitative variables allow one to formulate specific recommendations to governments in terms of economic policy.

Section 2 discusses in detail CEE-EU trade liberalization and institutional reforms undertaken by CEE countries. Sections 3 and 4, present the trade model, and the data employed. Baseline results are shown in Section 5. Endogeneity issues, the pro-trade effect of trade liberalization and institutional reforms are considered in Sections 6 and 7. In Section 8 we distinguish between general development (GD) and market transition (MT) institutions, and Section 9 summarizes the conclusions.

\section{European trade liberalization and institutional changes}

In the early 1990s all transition countries engaged in a strong process of trade liberalization with the EU. Despite the fact that timetables and specific measures differed from country to country, by the beginning of the twenty-first century each country's trade with the EU was characterized as almost entirely free. However, annual growth rates of CEE-EU bilateral trade are far from being uniform. One can easily see from Figure 1 that the major increase in CEE-EU bilateral trade occurred in the mid-1990s. Meanwhile, the majority of regional trade liberalization measures became effective after 1995, and can be held responsible only for the later growth of the bilateral trade. In the light of research on trade potential, the important early 
Figure 1. Annual growth rates of CEE-EU trade
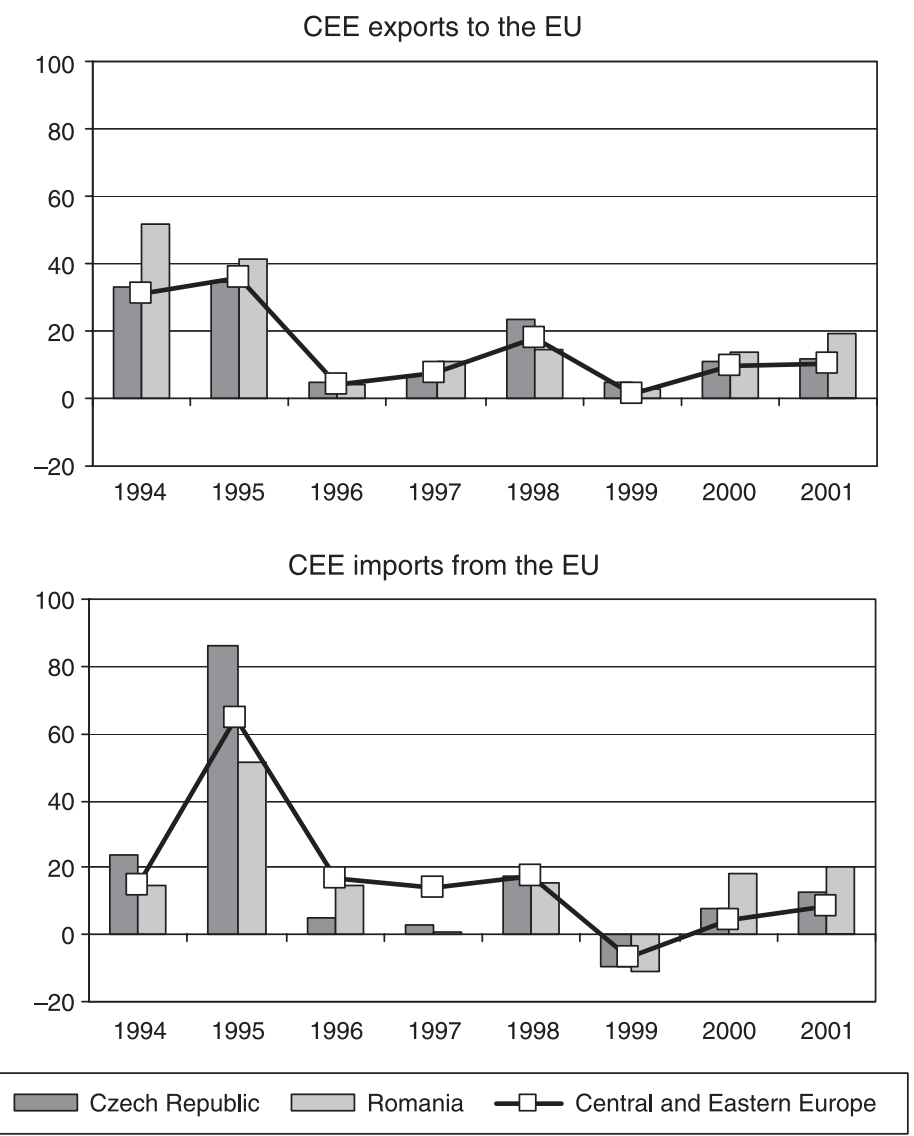

boom in the foreign trade of transition countries can be associated with their re-integration into the world economic system. ${ }^{2}$

Still, not all the growth of the trade of transition countries with the EU, even after 1995, can be imputed to regional trade liberalization. For instance, the highest growth rates of the exports of transition countries to their EU partners do not always correspond to the lowest values of the average EU import tariff (Table 1). Clearly, other factors are at work. The present paper focuses on the importance of

2 See Wang and Winters (1991), Baldwin (1993), Hamilton and Winters (1992), Harrigan (2003), Gros and Gonciarz (1996), Fontagné, Freudenberg and Pajot (1999) for a further discussion. 
Table 1. Export growth, trade liberalization, and quality of institutions in CEE

\begin{tabular}{|c|c|c|c|c|c|c|}
\hline Country & $\begin{array}{c}\text { Manufactured } \\
\text { exports to EU, } \\
1993-2000 \\
\text { growth rate }(\%)\end{array}$ & $\begin{array}{l}\text { Change in } \\
\text { average } \\
\text { EU tariff, } \\
1993-2000^{\mathrm{a}}\end{array}$ & $\begin{array}{c}\text { IEF score, } \\
2000^{\mathrm{b}}\end{array}$ & $\begin{array}{c}\text { EBRD } \\
\text { score, } \\
2000^{b}\end{array}$ & $\begin{array}{c}\text { Kaufmann } \\
\text { score, } \\
2000^{b}\end{array}$ & $\begin{array}{l}\text { Fraser } \\
\text { score, } \\
2000^{b}\end{array}$ \\
\hline Estonia & 647 & -2.75 & 0.67 & 0.62 & 0.68 & 0.68 \\
\hline Lithuania & 364 & -2.75 & 0.47 & 0.54 & 0.59 & 0.61 \\
\hline Slovakia & 323 & -4.25 & 0.50 & 0.55 & 0.59 & 0.54 \\
\hline Hungary & 288 & -6.17 & 0.63 & 0.68 & 0.68 & 0.63 \\
\hline Romania & 242 & -2.58 & 0.39 & 0.46 & 0.46 & 0.43 \\
\hline Czech Republic & 230 & -6.17 & 0.67 & 0.61 & 0.64 & 0.67 \\
\hline Latvia & 199 & -2.75 & 0.57 & 0.52 & 0.58 & 0.65 \\
\hline Bulgaria & 153 & -2.58 & 0.42 & 0.50 & 0.52 & 0.50 \\
\hline Poland & 149 & -6.14 & 0.53 & 0.62 & 0.64 & 0.52 \\
\hline Slovenia & 51 & -4.42 & 0.50 & 0.56 & 0.68 & 0.57 \\
\hline
\end{tabular}

Notes: a Change in percentage points between the first and the last year of the period for which data are available.

${ }^{\mathrm{b}} \mathrm{A}$ value closer to 1 corresponds to an increased level of a country's economic freedom, a better functioning of market institutions, or a better governance.

one such determinant - national institutions - both per se, and relative to foreign trade policy. Institutions have been shown to be strong determinants of economic growth. ${ }^{3}$ The literature on economic development points also to reversed causality between per capita gross domestic product (GDP) growth and the quality of institutions. Strong domestic institutions are an important precondition for economic growth, but are simultaneously shaped by the level of economic development of the country.

The examination of national-level institutions in connection with international trade is very recent in the literature. The pioneer paper on this subject is Anderson and Marcouiller (2002). It investigates the impact of corruption and imperfect contract enforcement on international trade patterns, and concludes that inadequate institutions constrain trade as much as the tariffs. Later work by Koukartchouk and Maurel (2003), de Groot et al. (2004), and Jansen and Nordas (2004) confirms this finding. Despite the different institutional aspects considered in these papers, they all rely on index measures for the quality of institutions. Turrini and Ypersele (2002),

\footnotetext{
${ }^{3}$ See Rodrik, Subramanian and Trebbi (2002), Frankel and Romer (1999), Warner and Sachs (1995). 
de Groot et al. (2004), and Duc et al. (2005) analyse the effect of similarity of the quality of governance, but without constructing a separate variable for institutional homogeneity. The possible endogeneity between trade and institutions is ignored in all of the above studies.

The present paper complements this literature in several ways. First, we consider two types of institutions: general development (GD) institutions, and institutions specific to market transition (MT) of CEE economies. We also call the latter market institutions, as they reflect the development of functional market economies in these countries. Secondly, two distinct ways in which institutions affect trade are identified. Trade increases not only when it is supported by strong institutions in the importing and exporting countries, but also when the differences in the institutions between the two are small. Hence, countries with poor but similar institutions exchange more, because they have already acquired the experience by trading locally and by overcoming difficulties of the poor institutional environment. When other things are equal, engaging in transactions with partners from countries with similar institutional deficiencies means a lower burden.

Next, through the use of appropriate instrumental variables, we examine the reverse causality between trade and institutions. The quality of institutions can be influenced by the extent to which the country participates in international trade. A high openness to foreign trade intensifies the demand for better institutions, which can increase a government's willingness to improve existent institutions. Alternatively, trade per se can generate positive externalities, including the effect of learning about better institutions that exist abroad. Combining these arguments with findings in the literature on economic growth, we conclude that institutions shape both international trade and per capita GDP growth, yet remain sensitive to changes in either of the two. The present paper discusses only causality between trade and national institutions. Other mutual dependencies are explored in depth in the economic growth literature.

Central and Eastern Europe is a region where very significant institutional changes took place during the 1990s. The passage from a planned to a marketoriented economy induced major reforms in domestic institutions, although they were uneven across the region. Hence, the impact of institutional changes on trade is even more significant in the case of transition countries. Table 1 displays the scores of four institutional measures for CEE countries in the year 2000. The Index of Economic Freedom (IEF) of the Heritage Foundation shows the level of economic freedom within a country, and can be viewed as a measure of the quality of GD institutions. The composite index of the European Bank for Reconstruction and Development (EBRD) reflects the advance of the transition process, that is, of reforms meant to ensure the passage to the market economy. For comparability, the last two columns show the corresponding institutional scores, computed by Kaufmann et al. (2003), and by the Fraser Institute. Original scores have been rescaled in order to take values in the interval [0; 1]. A score closer to 1 corresponds to a higher level of the economic freedom in the country, better functioning of 
market institutions, or improved governance. Countries are ranked according to the growth rate of their exports to EU partners during the 1990s. By the beginning of the twenty-first century, EU tariffs on imports from CEE countries were almost completely eliminated. Table 1 shows that countries with higher institutional scores performed better in terms of exports to the EU. The largest increase in exports to the EU is found for countries with the best IEF score. One can conclude, therefore, that at least some part of the uneven CEE-EU trade growth displayed in Figure 1, comes from differences in national institutions. We think this is sufficient motivation for more serious investigation of causality between trade, institutions, and trade policy, which we undertake in the following sections.

\section{The trade model}

We build a trade model in which bilateral trade is affected by countries' economic environments. We apply the hypothesis of Anderson and Marcouiller (2002) that insecurity constrains trade by raising the price of goods, in a monopolistic competition setting, with firm level product differentiation as in Dixit and Stiglitz (1977) and Krugman (1980). As in Anderson and Young (2002), and Anderson and Marcouiller (2002), imperfect contract enforcement is reflected in a price mark-up equivalent to a hidden tax on trade. But unlike their case, our hidden transaction costs, associated with the insecurity of international trade, arise from poor institutions in both the importer's and the exporter's country. Moreover, the national character of these institutions is an additional source of fragmentation of the economic space, and constitutes by itself a barrier to cross-border exchange. Hence, we account for the role of both domestic and foreign institutions, as well as for their similarity.

Consumers in each country solve a two-step budgeting function. First, consumers determine the proportion of total expenditure $E_{j}$ to allocate to internationally traded goods, both foreign and domestic:

$$
E_{j}=\sum_{i} x_{i j} p_{i j}=\sum_{i} m_{i j}
$$

where $x_{i j}$ is the amount of goods that country $j$ buys from the producers of country $i, p_{i j}$ is the price of these goods, and the product $m_{i j}=x_{i j} p_{i j}$ gives the value of country $j$ 's imports from $i$. Secondly, the value of $E_{j}$ is distributed across consumed varieties. We assume that products are differentiated at firm level, that consumer preferences are homothetic, of CES form, and identical across countries and varieties. The utility of a representative consumer from the importing country $j$ is then given by

$$
u_{j}=\left(\sum_{i} \sum_{r_{i}=1}^{n_{i}} x_{i j i_{i}}^{\frac{\sigma-1}{\sigma}}\right)^{\frac{\sigma}{\sigma-1}}
$$


where $n_{i}$ represents the number of varieties produced and exported by country $i$, and at the same time, the number of firms in country $i$, because each variety is produced by a separate firm.

The demand in country $j$ for goods produced in $i$ is obtained by solving the optimization problem, in which importing country consumers maximize their utility (2) subject to the budget constraint (1):

$$
m_{i j}=n_{i}\left(\frac{p_{i j}}{P_{j}}\right)^{1-\sigma} E_{j} .
$$

The denominator in Equation (3) is an importer-specific non-linear price index, representing the average price of internationally traded varieties to consumers from country $j$ :

$$
P_{j}=\left(\sum_{k} n_{k} p_{k j}^{1-\sigma}\right)^{1 /(1-\sigma)} .
$$

A tractable trade equation is obtained by dividing the bilateral imports $m_{i j}$, expressed by (3), by the imports of the same country from a different partner. We choose a country's trade with itself as reference for purchases from all foreign partners, in order to relate our model to the literature on border effects. Non-linear price indices $P_{j}$, and the importer's expenditure on internationally traded goods $E_{j}$ simplify to give the following equation of relative demands:

$$
\frac{m_{i j}}{m_{j j}}=\frac{n_{i}}{n_{j}}\left(\frac{p_{i j}}{p_{j j}}\right)^{1-\sigma} .
$$

A confirmed finding in the recent literature is that countries trade significantly less with each other than the theory predicts (Trefler, 1995; McCallum, 1995). The difference is particularly strong when compared to trade within national borders, revealing a so-called border effect. Trade policy barriers and the quality of institutions are stated among the various explanations for this result. One way to evaluate the role these two factors play in economic integration is to compare their contribution in explaining the lower than expected trade volumes. Working with foreignto-domestic trade ratios, as in Equation (5), is very convenient for the estimation of border effects.

A single production factor, labour, is used to produce all varieties. All countries are assumed to have identical fixed and variable costs in terms of labour units: $F$ and $\mu$ respectively. 
In a monopolistic competition setup, producers face a constant price elasticity of demand, equal to the elasticity of substitution between varieties, $\sigma$, and maximize profits by setting the marginal cost equal to the marginal revenue:

$$
\mu w_{i}=p_{i}\left(\frac{\sigma-1}{\sigma}\right)
$$

Consequently, the unitary price of each variety can be expressed as a function of the number of labour units, $\mu$, used to produce it, of the unitary remuneration of labour force $w_{i}$, and of the elasticity of demand $\sigma$.

The market equilibrium with free entry of firms arises under average cost pricing, since new firms enter the market until all profits vanish:

$$
\mu p_{i}=\frac{F w_{i}}{q_{i}}+\mu w_{i}=w_{i}\left(\frac{F}{q_{i}}+\mu\right) .
$$

One can express the factory price, $p_{i}$, from Equation (6), and substitute it in the left hand side of Equation (7). Note, that the price of any variety produced in country $i$ is a linear function of country's wage, $w_{i}$. Wage on both sides of the equation simplifies, and the number of units of variety $i$ produced at equilibrium becomes a function of invariable amounts, $F, \mu$, and $\sigma$ :

$$
q_{i}=\frac{F(\sigma-1)}{\mu} .
$$

With symmetric varieties, equal quantities $q \equiv[F(\sigma-1)] / \mu$ of each variety are produced. The output, $y_{i}$, of country $i$ equals the sum of outputs of its firms, evaluated at producer prices, $p_{i}$ :

$$
y_{i}=n_{i} q p_{i}
$$

We also allow prices at destination $p_{i j}$ to differ from country to country proportionally to bilateral trade costs, $\tau_{i j}$ :

$$
p_{i j}=p_{i} \tau_{i j}
$$

It is thus implicitly assumed that all partners are charged the same factory price.

Expressing $n_{i}$ from (9), and $p_{i}$ from (6), and substituting expression (10) in trade Equation (5), one gets the following expression of relative demands: 


$$
\frac{m_{i j}}{m_{j j}}=\frac{y_{i}}{y_{j}}\left(\frac{p_{i}}{p_{j}}\right)^{-\sigma}\left(\frac{\tau_{i j}}{\tau_{i j}}\right)^{1-\sigma} .
$$

Next, we consider the structure of trade costs, $\tau_{i j}$. The price of a good consumed in the importing country $j$ exceeds the producer price by the transport cost, the import tariff, the tariff equivalent of non-tariff barriers, and an 'insecurity' markup. The latter represents hidden transaction costs associated with the non-existence or the poor functioning of national institutions (as defined in Section 2). Anderson and Marcouiller (2002) show that the magnitude of this insecurity mark-up depends on the quality of national institutions. ${ }^{4}$

The fulfilment of a cross-border transaction involves a set of procedures to be accomplished in the exporting and importing country. The search for a foreign partner, the negotiation of the trade contract, the shipment of goods across the border, clearing the customs, and the international payment imply a direct interaction with institutions of both countries. Therefore, the complexity of these operations, the associated costs and delays, as well as the success of the entire transaction, will be affected by the quality of domestic and foreign institutions.

Three sources of trade costs are identified here: transport costs, trade policy costs (both tariffs and non-tariff barriers), and institutional costs:

$$
\begin{aligned}
\tau_{i j}= & d_{i j}^{\rho}\left(1+t_{i j}\right)\left(\exp \left(n t b_{i j}\right)\right)^{\eta}\left(\exp \left(S_{i}\right)\right)^{\gamma_{1}}\left(\exp \left(S_{j}\right)\right)^{\gamma_{2}}\left(\exp \left|S_{i}-S_{j}\right|\right)^{\gamma_{3}} \\
& \exp \left(\left(1-\text { home }_{i j}\right) b_{i j}\right) .
\end{aligned}
$$

Transport costs are instrumented by the distance. The ad valorem import tariff, $t_{i j}$, generates a linear increase of total trade costs, and raises the price precisely in proportion to the tariff. Non-tariff barriers (NTB) have a similar effect, but are considerably more difficult to measure. We use the NTB trade coverage and frequency ratios to quantify the level of these barriers, denoted by $n t b_{i j}$ in Equation (12).

Variables $S_{i}$ and $S_{j}$ reflect the quality of institutions in countries $i$ and $j$ respectively. As better institutions facilitate trade and reduce additional transaction costs, we expect coefficients $\gamma_{1}$ and $\gamma_{2}$ to be negative. ${ }^{5}$ As shown by de Groot et al. (2004), it is not only the quality of institutions in the trading countries that matters for bilateral trade, but also the institutional similarity or homogeneity. We account for this aspect by introducing a variable institutional distance, the inverse of institutional similarity, in the structure of trade costs (12). Partners from countries with similar institutions are more familiar with each other's formal procedures, conventions,

\footnotetext{
${ }^{4}$ Institutions for the defence of trade, and factors that allow traders to use those institutions successfully, are considered by Anderson and Marcouiller (2002).

${ }^{5}$ Notice that $S_{i}$ and $S_{j}$ need not contain the same elements. It is possible, and even very likely, that different things promote (impede) trade in the origin and the destination country. However, this aspect cannot be investigated with the trade specification developed by this model.
} 
norms of behaviour, and even business practices. When engaging in bilateral trade transactions, they also face reduced adjustment costs, and lower insecurity, relative to the natural unfamiliarity of the international environment. Similarity of informal business procedures may increase bilateral trust, and institutional similarity increases the compatibility of trading partners, which could explain a fair amount of the border effect. In our specific case, this suggests a positive weight, $\gamma_{3}$, of the absolute difference between the qualities of institutions of the two countries.

There may be complementary cross-border costs, $b_{i j}$, other than the ones described above. While we are unable to identify their source, we can still quantify them, by introducing a factor that takes for international transactions values greater than 1 in Equation (12). The variable home $i j$ is a dummy that denotes whether trading partners are from the same country, and $\left(\exp \left(b_{i j}\right)-1\right) \times 100$ is the tariff equivalent of border-specific trade barriers on country $i$ exports to $j$, different from tariffs, NTB, and institutions.

In contrast to the trade costs specification given by (12), the literature on border effects divides trade costs into two broad categories: those corresponding to costs common to all flows, continuous across space, and those standing for borderspecific costs, that occur only when traded goods cross international borders. Representative for the first category are transport costs, which arise for both international and domestic transactions. The presence of border-specific costs, such as tariffs and different institutional environments, generates discontinuous shifts in trade costs and flows. Therefore, tariff and non-tariff barriers, and the non-uniformity of national institutions account at least for a partial explanation of border effects. The quality of institutions, however, matters for all trade flows, foreign and domestic, and refers to the first type of trade costs. For internal shipments, the second, the third, and the last two factors of the right hand side of Equation (12) disappear. Domestic trade costs are given by:

$$
\tau_{j j}=d_{j j}^{\rho} \exp \left(\gamma_{4} S_{j}\right)
$$

Note, that if institutions matter for domestic trade as much as they do for foreign trade flows, then the following identity should hold: $\gamma_{4}=\gamma_{1}+\gamma_{2}$. Different functional forms for internal and cross-border trade costs, with respect to the quality of an institution, may be an additional source of lower than expected international trade. However, in the absence of supporting evidence, this aspect is considered only partially in Sections 7 and 8.

Substituting Equations (12) and (13) into the relative demand Equation (11), and taking log, we get:

$$
\begin{aligned}
\ln \frac{m_{i j}}{m_{j j}}= & \ln \frac{y_{i}}{y_{j}}-\sigma \ln \frac{w_{i}}{w_{j}}+\rho(1-\sigma) \ln \frac{d_{i j}}{d_{j j}}+(1-\sigma) \ln \left(1+t_{i j}\right) \\
& +\eta(1-\sigma) n t b_{i j}+\gamma_{1}(1-\sigma)\left(S_{i}-S_{j}\right)+\gamma_{3}(1-\sigma)\left|S_{i}-S_{j}\right|+(1-\sigma) b_{i j} .
\end{aligned}
$$


There are two institutional terms on the right hand side of Equation (14). The difference in the quality of national institutions of the exporting and importing country $\left(S_{i}-S_{j}\right)$ reflects the impact of institutions of the exporting country on crossborder, relative to domestic, trade. The absolute difference $\left|S_{i}-S_{j}\right|$ shows how the dissimilarity between institutional environments of the trading countries affects the trade between them. A positive coefficient for the former variable testifies that improved national institutions increase trade, while an estimated negative coefficient for the latter reveals the positive role of institutional homogeneity. Note, that the two measures can be highly correlated, which may produce biased and nonsignificant estimates of the corresponding coefficients. Even if the estimation of the true effects on trade of each of the two institutional measures is not possible due to the presence of multicollinearity, one can still judge which of the two measures is more important. In this case, dropping one of the two variables from Equation (14), one can identify the main channel through which institutions shape trade flows. The sign of the estimated coefficient on the left institutional variable will indicate the prevalence of the quality of institutions, or of the institutional similarity.

To compare the explanatory power of changes in foreign trade policy with that of changes in the institutional environment, we estimate the total border effect between trading countries $i$ and $j$, the residual border effect unexplained by tariffs and NTB, and the residual border effect unexplained by the institutional variables. The total effect reflects the loss in trade caused by all cross-border barriers, and is obtained as the exponential of the constant of the model, when all border-specific costs in (12) are replaced by a single term, $\exp \left(\left(1-h_{o m e}\right) B_{i j}\right)$ :

$$
\ln \frac{m_{i j}}{m_{j j}}=\ln \frac{y_{i}}{y_{j}}-\sigma \ln \frac{w_{i}}{w_{j}}+\rho(1-\sigma) \ln \frac{d_{i j}}{d_{j j}}+\gamma_{1}(1-\sigma)\left(S_{i}-S_{j}\right)+(1-\sigma) B_{i j} .
$$

Now we can introduce the trade policy variables $\ln \left(1+t_{i j}\right)$ and $b n t_{i j}$ in Equation (15). The exponential of the resulting constant term gives the corresponding residual border effect, that is, the drop in trade produced by all border-specific trade barriers except tariffs and NTB. Similarly, one can estimate the residual border effect with institutional variables. The computation of the increment in trade, induced separately by trade liberalization and by institutional reforms, is then straightforward.

In the empirical part of the paper we focus on the coefficients of the tariffs, of $\mathrm{NTB}$, and of the institutional variables, as features of the economic environment of the trading countries. In our model both factors have an impact on trade through trade costs. Trade liberalization, and an improved functioning of national institutions reduce transaction costs, and yield lower prices of exchanged goods charged to consumers. Institutional reforms may have an even stronger effect on trade as they also increase the homogeneity of the institutional environment: better institutions are at work in all countries. We assume full similarity when trading partners are from the same country. 
However, working with relative demands, $m_{i j} / m_{j j}$, implies the knowledge of both foreign and internal trade values. Unlike the case of international trade, only very few countries provide data on true trade flows taking place inside national borders. To overcome this limitation, one can follow Wei (1996), and compute internal trade as the difference between a country's production and its exports to all partners. This approach, however, yields biased results for at least two reasons. First, it does not permit controlling for non-tradable goods, and thus inflates internal trade and border effects. Secondly, it can produce negative values of internal trade for large levels of re-exports.

A possible way to tackle this problem is to use a different dependent variable. Rather than taking the foreign-to-domestic trade ratio, we can divide the exports of country $i$ to $j$ by the exports of a reference country $k$ to the same importing country $j$ :

$$
\begin{aligned}
\ln \frac{m_{i j}}{m_{k j}}= & \ln \frac{y_{i}}{y_{k}}-\sigma \ln \frac{w_{i}}{w_{k}}+\rho(1-\sigma) \ln \frac{d_{i j}}{d_{k j}}+(1-\sigma) \ln \frac{\left(1+t_{i j}\right)}{\left(1+t_{k j}\right)} \\
& +\eta(1-\sigma)\left(n t b_{i j}-n t b_{k j}\right)+\gamma_{1}(1-\sigma)\left(S_{i}-S_{k}\right) \\
& +\gamma_{3}(1-\sigma)\left(\left|S_{i}-S_{j}\right|-\left|S_{k}-S_{j}\right|\right)+(1-\sigma)\left(b_{i j}-b_{k j}\right) .
\end{aligned}
$$

In this way only international trade data are employed. Due to the specific form of the dependent variable, the quality of institutions of the importing country, $j$, drops out from Equation (16). The difference between the quality of national institutions in the exporting and the reference country accounts for the role of well- or mal-functioning national institutions in generating trade, but institutional heterogeneity is displayed then by a more complex term than in (14). The two institutional dimensions considered are better separated under the trade specification (16), reducing the risk of multicollinearity. Although in this case one can no longer estimate the border effects, the importance of reforms of institutions relative to trade liberalization, as factors stimulating trade, can be judged, comparing the trade creation effects of total trade liberalization, and of completed institutional reforms. Note, that comparing absolute values of coefficients of the relevant variables is misleading, as they are directly dependent on the units used.

Thus, we employ trade specification (14) to quantify the relative importance of trade liberalization and of institutional reforms (the two strategies that countries can adopt to intensify mutual trade), and (16) to differentiate between the impact of the quality of institutions and that of the institutional diversity.

\section{The data}

In this paper, we use data on the bilateral trade between 24 countries of the now enlarged EU: the 15 states who were members of the EU on 1 January 2004, 8 of the 10 
who joined the Union in May 2004 (not Cyprus and Malta), and the 2 countries of the latest accession (Romania and Bulgaria). ${ }^{6}$ Throughout the paper I call the first 15 members EU countries, and the 10 Central and East European countries - CEE or transition countries. I focus on the time period 1993 to 2000, when these countries undertook important measures of trade liberalization, and reforms of their national institutions. The almost complete liberalization of trade between EU and CEE countries at the end of the studied period was accompanied by a significant intensification of regional CEE trade. The passage of transition countries from a centrally planned system to a market economy called for radical transformations of the institutions, the elimination of some structures, and the establishment of new ones. Even though the reform of the institutions is vital for the transition process, it did, and continues to face, strong political and social opposition in many CEE countries. Hence, it is more difficult to implement institutional reforms than to eradicate regional tariffs and NTB. Meanwhile, the national institutions of the EU countries changed very little. In the empirical part of the paper, we explore this variation in the trade policy and the institutional environment of the sample (see Appendix A).

The data on bilateral manufactured trade $m_{i j}$ are obtained from the COMTRADE (World Bank) database. Domestic trade, $m_{j j}$, that is, imports of a country from itself, is computed following Wei (1996), as the difference between domestic production and the sum of exports to all foreign partners. The ratios $m_{i j} / m_{j j}$, and $m_{i j} / m_{k j}$ are calculated by dividing bilateral imports by the value of domestic trade and by the value of imports from Germany, the reference country, respectively. Production and wage data come from the World Bank-UNIDO database 'Trade and Production'. Missing data have been completed using the STAN database of OCDE for production, and the 'NewCronos' database of Eurostat for wages.

To avoid the identification of a country with its capital (or largest) city, international distances are computed as the population-weighted average of interregional distances. Each country is divided into comparable territorial units corresponding to the EU's NUTS II regions. The distance between two regions is simply the distance between largest cities. Internal distances $d_{j j}$ are computed following the same principle in order to ensure comparability of the two measures: as the population-weighted average distance from each region to all regions of the country, including itself. ${ }^{7}$ In the case of small countries, with only 1 NUTS II region, we use the breakdown into NUTS III regions. The distance of a region from itself, what we call intra-regional distance, is computed as by Head and Mayer (2000): namely two-thirds of the radius of a circle equal in area to the region. This is equivalent to the average distance between local producers and consumers, when each region is

\footnotetext{
${ }^{6}$ Belgium and Luxembourg are aggregated into a single observation.

${ }^{7}$ Helliwell and Verdier (2001), and Head and Mayer (2000) show the importance of the internal geography of trading countries in shaping trade flows.
} 
identified with a circle of an equal area, where producers are concentrated in the centre, and consumers are equally spread in the entire region.

Tariffs, and NTB coverage and frequency ratios are calculated using Haveman's database, constructed originally from the TRAINS database of UNCTAD. There are no tariff declarations for imports of Bulgaria and Slovakia. In Haveman's database, tariffs are reported at a very detailed level (the six-digit HS classification). We aggregate the tariff and NTB data across manufactured products to match the data on production, wages, and trade, using the value of the global imports as weights. This choice is motivated by the fact that the only other data available, for the level of disaggregation of tariffs and NTB, are the data on trade flows. We minimize the endogeneity bias, due to the correlation between trade and tariffs, by weighting the import tariffs of each country by world imports. Alternatively, Bouët et al. (2001) use as weights the imports of a group of countries with a large share in global trade. The NTB coverage ratio is computed as the volume of trade subject to at least one non-tariff measure, and is expressed as a percentage of total bilateral trade. The NTB frequency ratio is obtained by dividing the number of bilateral non-tariff measures by the total number of tariff lines. By construction, both NTB coverage and NTB frequency take values between 0 and 1 . Small values of NTB coverage and frequency ratios mean that non-tariff restrictions apply either to a smaller part of bilateral imports, or to a smaller number of traded products, and only zeros testify to the absence of any NTB for a given pair of countries.

We consider five sources of institutional variables: indices computed by the European Bank for Reconstruction and Development (EBRD), by the Heritage Foundation, by the Fraser Institute, by Kaufmann et al. (1999) and Kaufmann et al. (2003), and the World Bank's World Development Indicators (WDI). The first four are used as measures of the quality of national institutions, and the last quantify different aspects of the institutional framework.

The main results in this article are obtained with the EBRD and Heritage Foundation indices. The EBRD evaluates the status quo of the institutional environment of CEE countries, and the progress achieved by them in the transition process. We employ nine distinct measures of the quality of countries' institutions, published by the EBRD on an annual basis, separately and aggregated as a single index computed as their arithmetic mean. ${ }^{8}$ These indices take values from 1 to 4 , with a higher score indicating fuller or better implemented reforms. The EBRD indicators assess the quality of MT institutions, specific to the transition process, and are computed only for CEE countries. In order to fully explore the information incorporated in these measures, we assume that all EU members have well-functioning market economies, graded 4 according to the EBRD scale. Accordingly, since most international bodies set Western European economies as the main guideline for CEE countries' transition process, we consider CEE institutions to be fully compatible

\footnotetext{
${ }^{8}$ A more detailed discussion of component measures of the EBRD index is presented in Appendix A.
} 
Table 2. Institutional scores for EU and CEE countries

\begin{tabular}{lccccc}
\hline Variable & No. of observations & Mean & SD & Minimum & Maximum \\
\hline IEF for EU & 80 & 0.67 & 0.08 & 0.47 & 0.81 \\
IEF for CEE & 55 & 0.50 & 0.10 & 0.28 & 0.67 \\
Kaufmann for EU & 42 & 0.79 & 0.07 & 0.62 & 0.89 \\
Kaufmann for CEE & 30 & 0.59 & 0.07 & 0.46 & 0.69 \\
Fraser for EU & 28 & 0.71 & 0.06 & 0.58 & 0.82 \\
Fraser for CEE & 20 & 0.52 & 0.10 & 0.31 & 0.68 \\
EBRD for EU & 112 & 1.00 & 0.00 & 1.00 & 1.00 \\
EBRD for CEE & 80 & 0.59 & 0.12 & 0.24 & 0.83 \\
\hline
\end{tabular}

Note: Scores are re-scaled to take values from 0 to 1 .

with the market economy when they reach the same score as the institutions of EU countries. This adjustment is compatible with observed scores for other institutional variables of the two groups of countries, shown in Table 2. Even though the other three indices exhibit some variation of scores across EU countries, CEE countries always obtain lower scores. Moreover, the maximal CEE score never exceeds the average value of the same indicator for EU members.

The Heritage Foundation measures the quality of institutions in a country by an Index of Economic Freedom (IEF), published since 1995, for a large number of countries. IEF is computed as the simple average of ten component indices, corresponding to an equal number of institutional dimensions, and takes values from 5 to $1 .{ }^{9}$ A score of 1 denotes an institutional framework and a set of policies that are most propitious to economic freedom. The use of IEF implies a reduction of the time range of the analysis, but, unlike the case of the EBRD composite index, it is possible for all countries in the sample. To avoid multicollinearity between institutional and trade liberalization measures, we re-define the IEF index as the average of its component indices, less trade policy.

The Fraser Institute has developed an index of economic freedom of the world (EFW), which measures the consistency of a nation's policies and institutions with economic freedom. It is published in the institute's annual report 'The economic freedom of the world' and is currently available for 123 countries. The index measures the degree of economic freedom present in five major areas: (1) the size of the government, expenditures, taxes, and enterprises; (2) the legal structure and the security of property rights; (3) the access to sound money; (4) the freedom to trade internationally; and (5) the regulation of credit, labour and business. Unlike the previous measures, the EFW index is computed only for two out of the eight years of our sample.

\footnotetext{
${ }^{9}$ A more detailed discussion of component measures of IEF is presented in Appendix A.
} 
Figure 2. The correlation of institutional variables

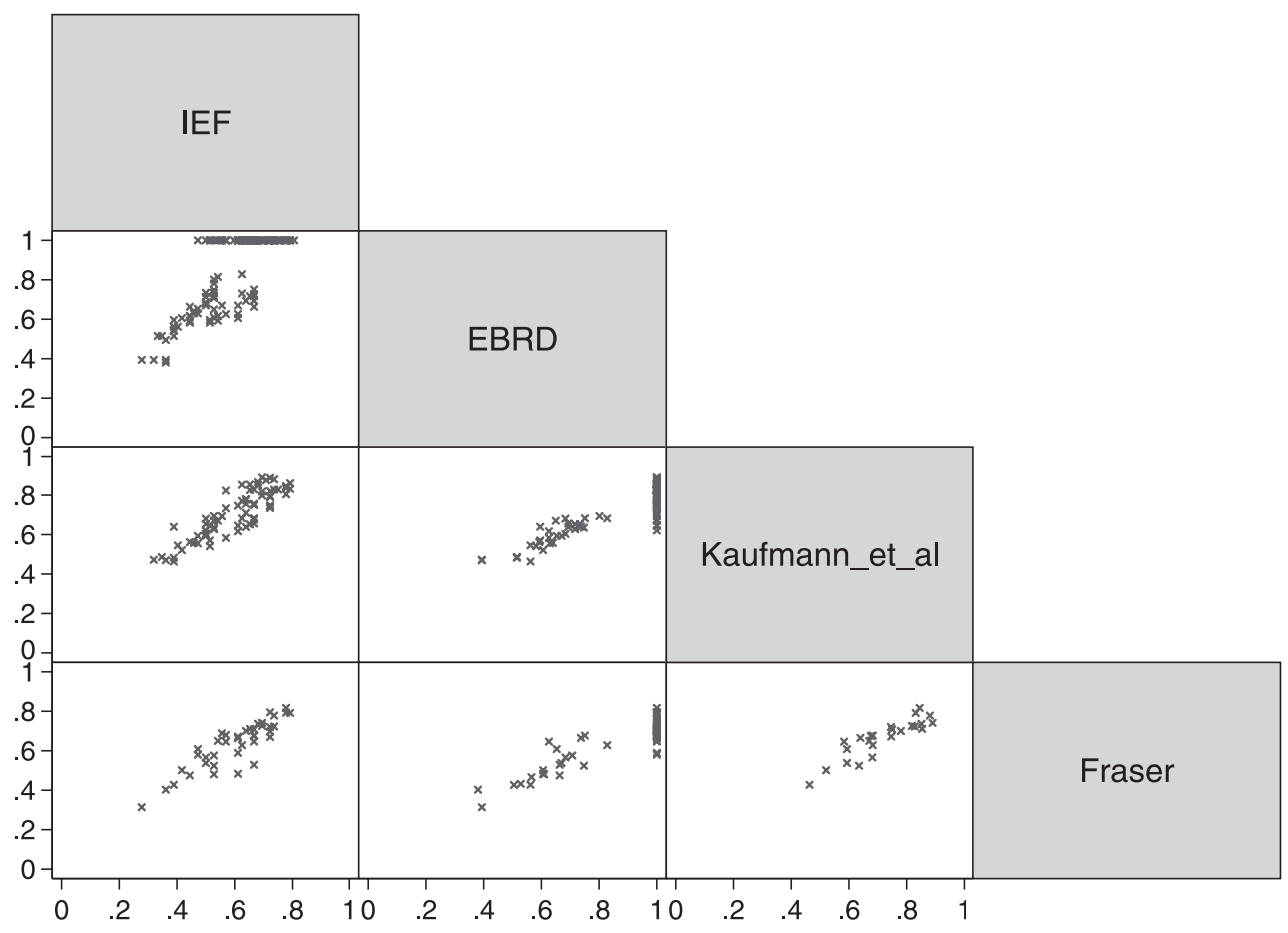

Kaufmann et al. (2003) estimate six dimensions of a country's governance for four distinct years: 1996, 1998, 2000, and 2002. Their indicators are based on several hundred variables measuring the perceptions of governance, drawn from 37 separate data sources constructed by 31 different organizations. We construct a global indicator for the quality of a country's institutions as the simple average of these six governance indicators.

We re-scale all institutional indicators to take values between 0 and 1, with a score close to 0 indicating a poor institutional framework, absence of reforms, and low economic freedom. The four institutional measures are highly correlated with each other, as shown in Figure 2. Therefore, we use them separately in the estimations. Additional continuous institutional measures, from the World Development Indicators database, and from the EBRD Transition Report, are used in the paper to instrument the quality of the institutions, reflected by the four institutional indices discussed above, and to characterize more accurately various aspects of the institutional environment.

Descriptive statistics and correlation coefficients for institutional and trade policy variables are shown in Tables A1 and A2 of Appendix A. 


\section{Baseline estimations and results}

In the empirical part of this paper, we estimate first the impact of institutions and trade policy instruments on cross-European trade, using global measures for the institutions of the countries. Secondly, we test for the presence of a mutual dependency between trade and institutions and use instrumental variables techniques to correct for endogeneity. Then, we assess the contribution of each factor in promoting trade, computing the share of cross-border costs it explains, and the supplementary trade flows it generates. Last, we investigate the different institutional aspects and employ quantitative institutional variables in order to draw specific policy recommendations.

We turn now to the estimation of the impact of trade liberalization (the reduction of tariffs and non-tariff barriers) and of the institutional framework, on trade between European nations. The first problem we face is finding good measures for the quality of national institutions. There are multiple measures which evaluate various institutional aspects. Besides the measures discussed in Section 4, empirical studies have also employed the Freedom House country ratings, the Euromoney country risk index, the ICRG risk ratings, the BERI index of contract enforceability, and others.

Useful insights can be gained by considering the quality and the functioning of the entire institutional framework of a country. For that, a single overall institutional measure, incorporating different institutional aspects, should be used. This simplifies the comparison of the importance for trade of national institutions versus that of foreign trade policy. In order to quantify the quality of national institutions, we restrict ourselves to the IEF and EBRD indices. For comparability reasons, however, we also report results obtained using Kaufmann et al. (2003), and Fraser Institute institutional indices. The Index of Economic Freedom is employed to picture GD institutions, and the European Bank for Reconstruction and Development index to show the state and the advancement of MT institutions.

We estimate the demand for foreign products relative to domestic demand using Equation (14). Since we analyse trade between countries of the same geographic area, sharing common historical and linguistic backgrounds, we account for these aspects in estimations:

$$
\begin{aligned}
\ln \frac{m_{i j}}{m_{j j}}= & \beta_{0}+\beta_{1} \ln \frac{y_{i}}{y_{j}}+\beta_{2} \ln \frac{w_{i}}{w_{j}}+\beta_{3} \ln \frac{d_{i j}}{d_{j j}}+\beta_{4} \text { border }_{i j}+\beta_{5} \text { lang }_{i j}+\beta_{6} \text { country }_{i j} \\
& +\beta_{7} \ln \left(1+\operatorname{tariff}_{i j}\right)+\beta_{8} n t b_{i j}+\beta_{9} \text { InstitDif }_{i j}+\beta_{10} \text { InstitDist }_{i j}+e_{i j}
\end{aligned}
$$

where border $_{i j}$, lang lij $_{\text {, }}$ and country $y_{i j}$ are dichotomic variables, corresponding respectively to the existence of a common land border between countries $i$ and $j$, of the same language spoken by individuals in both countries, and the fact that $i$ and $j$ formed a single country in the past. The last two variables in (17) reflect the nominal and the absolute difference in the quality of institutions of the two 
countries. Note, that (17) resembles the standard gravity equation, suggesting that similar values and signs of the coefficients should be found.

The results of the estimation of (17), with ordinary least squares and year dummies, and with generalized least squares, appear in Table 3. The different columns correspond to the four institutional measures employed. Estimates with the re-scaled Index of Economic Freedom are shown in column 1. The choice of relative demand as the explained variable introduces spatial autocorrelation in the error

Table 3. Relative demand for foreign products: importing country as reference

\begin{tabular}{|c|c|c|c|c|}
\hline \multirow{3}{*}{ Model: } & \multicolumn{4}{|c|}{ Dependent variable: $\ln m_{i j} / m_{j j}$} \\
\hline & (1) & (2) & (3) & (4) \\
\hline & IEF OLS & EBRD OLS & Kaufmann OLS & Fraser OLS \\
\hline \multirow[t]{2}{*}{ Intercept } & $-2.83^{* * *}$ & $-2.72^{* * *}$ & $-2.71^{* * *}$ & $-2.75^{* * *}$ \\
\hline & $(0.20)$ & $(0.17)$ & $(0.22)$ & $(0.22)$ \\
\hline \multirow[t]{2}{*}{ In production ratio } & $0.73^{* * *}$ & $0.75^{* * *}$ & $0.72^{* * *}$ & $0.71^{* * *}$ \\
\hline & $(0.04)$ & $(0.04)$ & $(0.05)$ & $(0.05)$ \\
\hline \multirow[t]{2}{*}{ ln wage ratio } & -0.20 & -0.27 & -0.42 & -0.27 \\
\hline & $(0.16)$ & $(0.18)$ & $(0.27)$ & $(0.25)$ \\
\hline \multirow[t]{2}{*}{ ln distance ratio } & $-0.57^{* * *}$ & $-0.66^{* * *}$ & $-0.52^{* * *}$ & $-0.60^{* * *}$ \\
\hline & $(0.13)$ & $(0.10)$ & $(0.12)$ & $(0.13)$ \\
\hline \multirow[t]{2}{*}{ Common border } & $0.73^{* * *}$ & $0.73^{* * *}$ & $0.73^{* * *}$ & $0.70^{* * *}$ \\
\hline & $(0.15)$ & $(0.11)$ & $(0.16)$ & $(0.14)$ \\
\hline \multirow[t]{2}{*}{ Common language } & $0.74^{* * *}$ & $0.68^{* * *}$ & $0.65^{* * *}$ & $0.69^{* * *}$ \\
\hline & $(0.16)$ & $(0.15)$ & $(0.18)$ & $(0.17)$ \\
\hline \multirow[t]{2}{*}{ Same country } & $1.62^{* * *}$ & $1.49^{* * *}$ & & \\
\hline & $(0.20)$ & $(0.14)$ & & \\
\hline \multirow[t]{2}{*}{$\ln (1+$ tariff $/ 100)$} & $-19.38^{* * *}$ & $-14.27^{* * *}$ & & \\
\hline & (3.19) & $(3.55)$ & & \\
\hline \multirow[t]{2}{*}{ NTB coverage } & 0.06 & -0.16 & & \\
\hline & (1.04) & $(0.31)$ & & \\
\hline \multirow[t]{2}{*}{ Institutions, quality } & 0.18 & 1.46 & 1.85 & 0.46 \\
\hline & $(1.01)$ & (1.12) & (1.40) & (1.48) \\
\hline \multirow[t]{2}{*}{ Institutions, distance } & -0.53 & $-1.32^{* *}$ & $-2.97^{* * *}$ & -1.19 \\
\hline & $(0.85)$ & $(0.64)$ & $(0.82)$ & (1.59) \\
\hline Year dummies & yes & yes & yes & yes \\
\hline No. of observations & 1,073 & 1,356 & 546 & 314 \\
\hline$R^{2}$ & 0.723 & 0.74 & 0.736 & 0.702 \\
\hline RMSE & 0.802 & 0.786 & 0.73 & 0.772 \\
\hline
\end{tabular}

(C) 2007 The Author

Journal compilation (C) 2007 The European Bank for Reconstruction and Development 
Table 3. (cont) Relative demand for foreign products: importing country as reference

\begin{tabular}{|c|c|c|c|c|}
\hline \multirow{3}{*}{ Model: } & \multicolumn{4}{|c|}{ Dependent variable: $\ln m_{i j} / m_{j j}$} \\
\hline & (5) & (6) & (7) & (8) \\
\hline & IEF GLS & EBRD GLS & Kaufmann GLS & Fraser GLS \\
\hline \multirow[t]{2}{*}{ Intercept } & $-2.99 * * *$ & $-2.86^{* * *}$ & $-3.47^{* * *}$ & $-3.32^{* * *}$ \\
\hline & $(0.03)$ & $(0.02)$ & $(0.03)$ & $(0.03)$ \\
\hline \multirow[t]{2}{*}{ In production ratio } & $0.72^{* * *}$ & $0.75^{* * *}$ & $0.75^{* * *}$ & $0.73^{* * *}$ \\
\hline & $(0.01)$ & $(0.00)$ & $(0.01)$ & $(0.01)$ \\
\hline \multirow[t]{2}{*}{ In wage ratio } & $-0.21^{* * *}$ & $-0.32^{* * *}$ & $-0.30^{* * *}$ & $-0.24^{* * *}$ \\
\hline & $(0.01)$ & $(0.02)$ & $(0.02)$ & $(0.01)$ \\
\hline \multirow[t]{2}{*}{ In distance ratio } & $-0.55^{* * *}$ & $-0.67^{* * *}$ & $-0.66^{* * *}$ & $-0.62^{* * *}$ \\
\hline & $(0.02)$ & $(0.01)$ & $(0.02)$ & $(0.01)$ \\
\hline \multirow[t]{2}{*}{ Common border } & $0.75^{* * *}$ & $0.72^{* * *}$ & $0.98^{* * *}$ & $0.87^{* * * *}$ \\
\hline & $(0.03)$ & $(0.02)$ & $(0.03)$ & $(0.02)$ \\
\hline \multirow[t]{2}{*}{ Common language } & $0.65^{* * *}$ & $0.68^{* * *}$ & $1.04^{* * *}$ & $0.96^{* * *}$ \\
\hline & $(0.04)$ & $(0.03)$ & $(0.06)$ & $(0.09)$ \\
\hline \multirow[t]{2}{*}{ Same country } & $1.53^{* * *}$ & $1.56^{* * *}$ & & \\
\hline & $(0.36)$ & $(0.08)$ & & \\
\hline \multirow[t]{2}{*}{$\ln (1+\operatorname{tariff} / 100)$} & $-19.05^{* * *}$ & $-14.02^{* * *}$ & & \\
\hline & $(0.42)$ & $(0.30)$ & & \\
\hline \multirow[t]{2}{*}{ NTB coverage } & 0.05 & $-0.43^{* * *}$ & & \\
\hline & $(0.07)$ & $(0.07)$ & & \\
\hline \multirow[t]{2}{*}{ Institutions, quality } & $0.19 *$ & $1.94^{* * *}$ & $1.25^{* * *}$ & $0.29^{* * *}$ \\
\hline & $(0.10)$ & $(0.11)$ & $(0.15)$ & $(0.11)$ \\
\hline \multirow[t]{2}{*}{ Institutions, distance } & $-0.68^{* * *}$ & $-1.43^{* * *}$ & $-1.21^{* * *}$ & $-3.23^{* * *}$ \\
\hline & $(0.12)$ & $(0.10)$ & $(0.12)$ & $(0.10)$ \\
\hline No. of observations & 1,073 & 1,356 & 546 & 314 \\
\hline Hausman specification test & 4.56 & 19.51 & 28.60 & 5.49 \\
\hline$P$-value & 0.34 & 0.03 & 0.00 & 0.24 \\
\hline Breusch and Pagan test & $1,418.91$ & $1,641.38$ & 430.49 & 90.53 \\
\hline$P$-value & 0.00 & 0.00 & 0.30 & 0.00 \\
\hline $\begin{array}{l}\text { Correlation of } \\
\text { institutional variables }\end{array}$ & 0.17 & 0.32 & -0.00 & 0.00 \\
\hline
\end{tabular}

Note: Standard errors in parentheses: ${ }^{* * *},{ }^{* *}$ and ${ }^{*}$ represent, respectively, statistical significance at the 1,5 and 10 per cent levels, respectively. 
term, for which we correct through a robust clustering procedure, that allows residuals for the same importing country to be correlated. All variables have coefficients of the expected sign and most of them are statistically significant. The coefficient on the production ratio is close to 1, and that of distance is within the range of values found in the literature. The small and non-significant estimate of the elasticity of substitution, $\sigma$, equal to the coefficient on the wage ratio with opposite sign, raises doubt about the use of wages as proxies for factory prices. This problem may be due to the fact that labour is the only considered production input. Nevertheless, endogeneity may also play a role here: large exports motivate firms to increase wages; imports boost or check domestic production, depending on the share of intermediate relative to final products. Positive coefficients for dummy variables controlling for common land border, for common language, and for common historical path, show the importance of non-economic factors in reducing international trade costs. Countries sharing a common land border or language trade two $[=\exp (0.74)]$ times more than countries that do not. The absence of international borders between two countries, at a certain point in the past, increases trade by five $[=\exp (1.64)]$ times.

The main parameters we are interested in are the coefficients of trade policy, and institutional variables. The import tariff enters Equation (17) with a large and strongly significant weight of -19.38 . The coefficient on the NTB coverage ratio is not significantly different from zero. The difference between the coefficients on tariffs and on wages is much larger than 1, contrary to what is predicted by the theory. This confirms the limits imposed by the assumption that labour is the single production factor. The large value of the coefficient on tariffs is due to the selected countries and years in the sample. The late 1990s were characterized by a general liberalization of European trade, and by a simultaneous re-orientation of CEE countries towards West European partners. The coefficients of the two institutional variables are of expected signs, but are not statistically significant. The point estimate for the difference in the quality of institutions reflects the effect of an equal simultaneous improvement of institutions in both countries, while the coefficient of the second institutional variable shows the discrepancy in the quality of these institutions. Low statistical significance may be explained by the use of inappropriate econometric techniques, and by the disregard of the two-way causality between trade and institutions, described in Section 2.

The negative and significant constant term indicates that there are important border specific trade costs left unexplained by tariffs, NTB, and the institutional environment. These additional trade barriers lead firms to trade about 17 [= $\exp (2.83)]$ times more with domestic, than with similar foreign partners.

In column 2 we estimate (17) using the EBRD index. The results are very similar to the previous ones, and all coefficients have expected signs. In addition, the coefficient for institutional distance is statistically significant, confirming the fact that similarity between national institutions generates more trade. To produce results more comparable to other findings in the literature, we use institutional 
indices developed by Kaufmann et al. (2003) (column 3), and the Fraser Institute (column 4), measures more frequently found in empirical studies. Compared with IEF and EBRD index, the Kaufmann and Fraser Institute measures are available for a smaller number of years. This restriction of the dataset removes all variation in tariff and non-tariff data, and the common historical path captured by the country dummy. Hence, one cannot estimate the coefficients for these variables. However, we find evidence of a positive impact on trade of the quality of institutions (although not statistically significant), and of their similarity. Point estimates for institutional variables with all four indices are of comparable magnitude. One can thus be pretty confident of obtaining credible results when restricting the choice to the IEF and EBRD index. ${ }^{10}$

In the second part of Table 3 we display results with panel estimation techniques. Cross-section time-series generalized-least-squares estimates of (17) are shown in columns 5 to 8 . We need to choose between a fixed-effect and a randomeffect estimator. The presence of explanatory variables invariant in time in Equation (17) makes it impossible to estimate coefficients with a fixed-effects procedure. However, in order to use random effects we need to test for the independence of the individual (in our case country-pair) error term, with respect to explanatory variables. The Breusch and Pagan Lagrangian multiplier test for random effects is highly significant for the IEF, the EBRD and the Fraser Institute indices, indicating that individual effects are not constant across time - a violation of the primary random-effects assumption. However, the Hausman test of fixed versus random effects specification indicates that very similar coefficients are obtained with both models: for all three indices the $\chi^{2}$ statistic is not significant at the 1 per cent level. In the case of the Kaufmann index, although the difference in coefficients is systematic $\left(\chi^{2}=28.60, P=0.00\right)$, the independence assumption of the individual term is validated. Therefore, we prefer the random to the fixed effects specification for all institutional measures. We also control for panel specific heteroscedasticity.

Interestingly, in this case coefficients of both institutional variables become significant, regardless of the index employed. We find evidence in support of both institutional channels identified in Section 3: countries trade more when they have both good and similar institutions. Moreover, the effect is significantly larger when MT institutions are targeted. Despite the fact that the variance of the level of economic freedom among European countries is comparable to that of the quality of market institutions, countries need to concentrate their efforts on the latter, in order to increase regional trade integration.

Thus, a 1 per cent drop in the average import tariff causes a 14 per cent to 19 per cent increase in bilateral relative to domestic trade, and a 5 percentage point drop can persuade firms in the importing country to buy twice as many products from

\footnotetext{
${ }^{10}$ The high correlation of the IEF and EBRD index with the Kaufmann and Fraser Institute indices, shown in Figure 2, also supports our choice of institutional variables.
} 
foreign partners. The significant estimated value of the coefficient on NTB in column 6 permits us to quantify the impact of these measures on trade: 1 per cent less of trade subject to NTB yields a 54 per cent $=[\exp ((-1) *(-0.43))-1]$ increase in foreign relative to domestic trade. Similarly, one standard deviation increase in the level of economic freedom of a foreign partner will lead to a 3.4 per cent $=[\exp (0.175$ * $0.19)-1]$ increase in imports from that country compared to domestic trade, and a comparable reduction of the institutional distance to that country - to a 6.6 per cent $=[\exp (0.10 *(-0.68))-1]$ increase of the trade ratio. Meanwhile, one standard deviation increase in the quality of MT institutions of a partner, and in the MT institutional distance generate respectively 79 per cent $=[\exp (0.30 * 1.94)-1]$, and 26 per cent $=$ $[\exp (0.21 *(-1.43))-1]$ more trade with that particular country compared to internal trade. Thus, it can be concluded that, despite the large effect of trade liberalization, institutional reforms remain an important trade-creating factor, and that, European trade will mostly benefit from improved market institutions of CEE countries. ${ }^{11}$

When the NTB coverage ratio in Equation (17) is replaced with the NTB frequency ratio, estimated coefficients are almost unchanged, both in terms of magnitude and of statistical significance. The coefficients of correlation between the institutional variables on the right hand side of (17) are indicated in the last line of Table 3. They are sufficiently low for one to worry about multicollinearity. For a robustness check, we also estimated Equation (17) with exporter fixed effects to control for multilateral resistance, and we obtain very similar values for all coefficients. One does not need to include importer fixed effects in this case because importer-specific resistance terms simplify when the $m_{i j} / m_{j j}$ ratio is the explained variable. Hence, the choice of the monopolistic competition trade model does not affect the conclusions formulated in the paper.

We use Equation (16) to estimate the impact of trade policy and of institutions on foreign trade, with imports from a third country as reference. As before, dummies for contiguity, common language, and political ties in the past are added as explanatory variables:

$$
\begin{aligned}
\ln \frac{m_{i j}}{m_{k j}}= & \gamma_{0}+\gamma_{1} \ln \frac{y_{i}}{y_{k}}+\gamma_{2} \ln \frac{w_{i}}{w_{k}}+\gamma_{3} \ln \frac{d_{i j}}{d_{k j}}+\gamma_{4}\left(\text { border }_{i j}-\text { border }_{k j}\right) \\
& +\gamma_{5}\left(\text { lang }_{i j}-\operatorname{lang}_{k j}\right)+\gamma_{6}\left(\text { country }_{i j}-\text { country }_{k j}\right)+\gamma_{7} \ln \frac{\left(1+\operatorname{tariff}_{i j}\right)}{\left(1+\operatorname{tariff}_{k j}\right)} \\
& +\gamma_{8} \frac{n t b_{i j}}{n t b_{k j}}+\gamma_{9} \text { InstitDif }_{k j}+\gamma_{10}\left(\text { InstitDist }_{i j}-\text { InstitDist }_{k j}\right)+\varepsilon_{i j} .
\end{aligned}
$$

We choose Germany, the main trading partner of most European countries, as the reference country $k$. Hence, the last two variables reflect (i) the difference in the

\footnotetext{
${ }^{11}$ According to the transformation of institutional variables, EU countries already possess well-functioning MT institutions.
} 
quality of institutions of the exporting country $i$ and Germany, and (ii) the difference between the institutional distance separating the country $j$ from $i$, and from Germany. Regardless of the complex form of these variables, the interpretation of their coefficients is the same as for institutional variable in (17). On the other hand, the economic meaning of the constant term in (18) is quite sophisticated. It represents the ratio between the border effect of country $j$ with $i$ and its border effect with Germany.

Coefficients estimated with (18), for each of the four institutional indices, are shown in Table 4 . As predicted by the theory, these values are very similar to those obtained by estimating (17). However, dividing imports from foreign European countries by imports of German products has several inconveniences. First, even if low prices attract foreign customers, they can also signal a poor quality of the traded goods. Consumers may prefer more expensive German products to cheaper products of a different origin simply because the difference in price can be compensated for by the higher quality of the German goods. Second, because seven countries from the sample share a land border with Germany, but only one shares a common language, and none was part of the same country as Germany, Equation (18) underestimates the impact of contiguity, and amplifies the effect of linguistic and historical ties on trade. Finally, trade specification (18) reduces the variance of the institutional variables, which leads to a drop in the statistical significance of the estimates.

\section{Endogeneity issues}

Another issue we want to discuss in detail in this article is the endogeneity in the estimated trade Equation (17). The presence of a mutual causality, between trade and the independent variables, can produce biased coefficients in OLS and GLS estimations. As already stated in Section 5, production and wage variables are one possible source of endogeneity. In particular, larger imports can favour domestic production, when the latter relies heavily on foreign intermediate inputs, but can also have a harmful effect if imported products crowd out local producers through increased competition on the domestic market. Wages, too, are affected by the performance of the country in foreign markets. This can be visualized within a country through the gap between employees' remuneration by exporting companies and their remuneration by local market-oriented firms. Last but not least, the quality of institutions can change with respect to the participation of the country in international trade. The exchange of large amounts of goods with foreign partners brings the firms more often into contact with deficiencies in the institutional framework, and can spur them to lobby for reforms in the system.

Consequently, one calls for appropriate econometric procedures when estimating the relative demand for foreign goods. This problem is usually solved by using the instrumental variable (IV) and the generalized method of moments (GMM) 
Table 4. Relative demand for foreign products: trade with Germany as reference

\begin{tabular}{|c|c|c|c|c|}
\hline \multirow{3}{*}{ Model: } & \multicolumn{4}{|c|}{ Dependent variable: $\ln m_{i j} / m_{k j}$} \\
\hline & (1) & (2) & (3) & (4) \\
\hline & IEF OLS & EBRD OLS & Kaufmann OLS & Fraser OLS \\
\hline \multirow[t]{2}{*}{ Intercept } & $35.12^{*}$ & -2.87 & 30.04 & $50.52^{* * *}$ \\
\hline & $(18.76)$ & $(18.41)$ & (19.56) & $(15.76)$ \\
\hline \multirow[t]{2}{*}{ ln production ratio } & $0.87^{* * *}$ & $0.86^{* * *}$ & $0.88^{* * *}$ & $0.86^{* * *}$ \\
\hline & $(0.03)$ & $(0.03)$ & $(0.03)$ & $(0.04)$ \\
\hline \multirow[t]{2}{*}{ ln wage ratio } & $0.22^{* * *}$ & $0.47^{* * *}$ & 0.14 & $0.28^{*}$ \\
\hline & $(0.07)$ & $(0.09)$ & $(0.15)$ & $(0.16)$ \\
\hline \multirow[t]{2}{*}{ ln distance ratio } & $-0.56^{* * *}$ & $-0.58^{* * *}$ & $-0.46^{* * *}$ & $-0.46^{* * *}$ \\
\hline & $(0.14)$ & $(0.13)$ & $(0.11)$ & $(0.14)$ \\
\hline \multirow[t]{2}{*}{ Common border } & $0.28^{* *}$ & $0.28^{* *}$ & $0.28^{* *}$ & $0.26^{* *}$ \\
\hline & $(0.12)$ & $(0.11)$ & $(0.12)$ & $(0.11)$ \\
\hline \multirow[t]{2}{*}{ Common language } & $0.93^{* * *}$ & $0.88^{* * *}$ & $0.91^{* * *}$ & $0.92^{* * *}$ \\
\hline & $(0.10)$ & $(0.10)$ & $(0.11)$ & $(0.09)$ \\
\hline \multirow[t]{2}{*}{ Same country } & $3.20^{* * *}$ & $2.97^{* * *}$ & & \\
\hline & $(0.25)$ & $(0.20)$ & & \\
\hline \multirow[t]{2}{*}{$\ln ((1+$ tariff $/ 100)$ ratio $)$} & $-15.14^{* * *}$ & -1.85 & & \\
\hline & $(4.03)$ & $(7.20)$ & & \\
\hline \multirow[t]{2}{*}{ NTB coverage } & $-1.84^{* * *}$ & $-1.08^{* *}$ & & \\
\hline & $(0.35)$ & $(0.46)$ & & \\
\hline \multirow[t]{2}{*}{ Institutions, quality } & $0.96^{* *}$ & $0.88^{*}$ & $2.60^{* * *}$ & $2.26^{* * *}$ \\
\hline & $(0.42)$ & $(0.46)$ & $(0.65)$ & $(0.60)$ \\
\hline \multirow[t]{2}{*}{ Institutions, distance } & 0.16 & -0.50 & $-1.23^{*}$ & $-2.77^{* * *}$ \\
\hline & $(0.53)$ & $(0.52)$ & $(0.65)$ & $(0.54)$ \\
\hline No. of observations & 1,017 & 1,306 & 507 & 314 \\
\hline$R^{2}$ & 0.862 & 0.868 & 0.884 & 0.877 \\
\hline RMSE & 0.562 & 0.558 & 0.466 & 0.48 \\
\hline
\end{tabular}

Note: Standard errors in parentheses: ${ }^{* * *},{ }^{* *}$ and * represent, respectively, statistical significance at the 1,5 and 10 per cent levels, respectively.

estimations. However, these approaches rely heavily on the availability of good instruments for each endogenous variable, i.e., for variables that are important determinants of a particular endogenous variable, but have no direct impact on the others. The literature acknowledges the difficulty of finding good instruments for all three variables mentioned above. 
In econometric terms, what counts is good instruments for the endogenous variables on the right hand side of (17) in order to find exogenous variations in production, wages, and institutions, and to explain relative trade. From a theoretical point of view, truly exogenous variations are unlikely to exist; it is necessary, therefore, to find sources of variation that are orthogonal to other determinants of trade. The theoretical model predicts a unitary coefficient on production. Thus, one can easily correct for endogeneity between trade and production in (17) by imposing $\beta_{1}=1$. Wages in a country are determined by demand and offer conditions on the labour market: the size of the labour force, the number of employers (firms) operating on the market, the bargaining power of the unions, and the productivity of labour. Of all these variables, only the last one passes the Sargan over-identification test with our data, and is used to instrument the variation in wage ratio in the first-stage estimations.

Endogenous institutions have been treated in the literature almost exclusively in connection with development related issues. For example, Acemoglu, Robinson and Johnson (2001) demonstrate their strong causality on per capita income. They use mortality rates of colonial settlers as an instrument for institutional quality, and find that the adopted instrument is strong. From that paper it is possible to conclude that the characteristic of the environment, as found by the colonists, is one of the most important reasons for their decision to settle in a certain area than in another. Moving away from the idea that geography can explain the variation of institutions, Easterly and Levine (2003), and others instrument institutions by using different geographic variables. They include different sets of instruments for endowments, such as the latitude, the fact of being (or not) landlocked, and ten different dummy variables representing minerals and crops.

However, all theses studies adopt an approach specific to the breakdown of the world into imperial states and their overseas territories. Therefore, the instruments they propose are irrelevant for institutions of European countries. In our case, instrumental variables need to account for specific differences between East and West European economies. None of the countries in our sample has been a former colony. Purely geographic aspects cannot explain differences in the functioning of institutions across the continent, either. Although countries from the North tend to have better institutions, the North-South passage to poorer institutions is far from being smooth. Moreover, one should be able to provide an economic justification for the causality between the chosen instruments and the endogenous explanatory variable.

We have considered an entire set of possible instruments for institutions, including mortality rate, share of non-tax revenue, patents deposed by residents and foreigners, share of rural population, market capitalization, percentage of listed domestic companies, share of traded stocks in the national product and per capita consumption of the central government. Plausible stories about the effect on the quality of institutions can be told for all these variables, but only three of them qualify as good instruments according to the Sargan test. 
The first instrument is the mortality rate. The intuition behind this is that a higher probability of dying soon diminishes people's valuation of future benefits, including those of well-functioning institutions. Therefore, there is less incentive for institutional reforms in countries with high death rates. Building better institutions is a long-term investment, and in some countries those who make the main effort may simply not be able to enjoy its future advantages. High mortality has the same effects as political instability for government officials, who, therefore, continue to accept bribery and corruption as everyday occurrences.

Market capitalization, expressed as a share of the domestic product, is the second instrument employed. It reflects simultaneously the share of listed companies, and the market value of their stock. A higher level of market capitalization illustrates a larger participation of firms on the stock exchange, a higher value of their assets, or both. All three situations lead to increased needs (and pressure) for strong institutions. The stock exchange can be viewed as an institution, and its condition can shed light on the state of the other institutions in the country.

The last eligible instrument for institutions is the government's tax revenue. It is generally accepted that the institutions of a country can change significantly only with sufficient support from the government. Support can come in two forms: political and financial. The ability of the government to collect taxes determines the amount of its funds, and as a consequence its capacity to finance institutional reforms. A severe limitation in funds on which the government can draw to finance its actions, reduces not only the scale of these actions but also their popularity among the electorate.

The estimates of (17) compatible with endogeneity are displayed in Table 5. To control for the panel structure of our data, country-pair effects have been included in all second-stage estimations. Wu-Hausman and Durbin-Wu-Hausman test statistics for the endogeneity are constructed, and are provided in the lower part of the table. The null hypothesis, associated with these tests, recognizes all the variables on the right hand side of (17) as exogenous. The alternative hypothesis requires wages and institutions to be endogenous. Because the results of these tests rely on the instruments selected, the Sargan test for the validity of instruments is conducted to determine whether the selected instruments are appropriate.

IEF is used in column 1 as a measure of the quality of institutions. Note, that limited availability of data about the selected instruments reduces the number of observations and the variance of other exogenous variables. Thus, the very low variation in import tariffs makes the estimation of $\beta_{7}$ impossible. The gain in statistical significance of the coefficients of institutional variables is very small, but is zero on wages. The large $P$-value for both $\mathrm{Wu}$-Hausman $(F=8.67, P=0.00)$ and Durbin-Wu-Hausman $\left(\chi^{2}=29.99, P=0.00\right)$ tests reveals that controlling for endogeneity is unnecessary. The absence of endogeneity also suggests that OLS and GLS estimations are reliable in this case.

Column 2 shows the results obtained with the EBRD composite institutional index. Both a large partial $R^{2}$ in first-stage regressions, and a low Sargan statistic 
Table 5. Relative demand for foreign products: endogeneity issues

\begin{tabular}{|c|c|c|c|c|c|c|}
\hline \multirow[b]{2}{*}{ Model: } & \multicolumn{6}{|c|}{ Dependent variable: $\ln m_{i j} / m_{j j}$} \\
\hline & $\begin{array}{l}\text { (1) } \\
\text { IEF } \\
\text { IV }\end{array}$ & $\begin{array}{c}(2) \\
\text { EBRD } \\
\text { IV }\end{array}$ & $\begin{array}{c}(3 a) \\
\text { Kaufmann } \\
\text { IV }\end{array}$ & $\begin{array}{c}(3 b) \\
\text { Kaufmann } \\
\text { GMM }\end{array}$ & $\begin{array}{l}\text { (4a) } \\
\text { Fraser } \\
\text { IV }\end{array}$ & $\begin{array}{l}(4 b) \\
\text { Fraser } \\
\text { GMM }\end{array}$ \\
\hline Intercept & $\begin{array}{l}-3.58^{* * *} \\
(0.41)\end{array}$ & $\begin{array}{l}-3.03^{* * *} \\
(0.15)\end{array}$ & $\begin{array}{l}-2.33^{* * * *} \\
(0.13)\end{array}$ & $\begin{array}{l}-2.31^{* * *} \\
(0.26)\end{array}$ & $\begin{array}{l}-2.37^{* * *} \\
(0.20)\end{array}$ & $\begin{array}{l}-2.28^{* * *} \\
(0.26)\end{array}$ \\
\hline In production ratio & 1.00 & 1.00 & 1.00 & 1.00 & 1.00 & 1.00 \\
\hline ln wage ratio & $\begin{array}{l}-0.25 \\
(0.22)\end{array}$ & $\begin{array}{l}-1.03^{* * *} \\
(0.13)\end{array}$ & $\begin{array}{l}-1.44^{* * *} \\
(0.15)\end{array}$ & $\begin{array}{l}-1.43^{* * *} \\
(0.30)\end{array}$ & $\begin{array}{l}-1.35^{* * *} \\
(0.22)\end{array}$ & $\begin{array}{l}-1.23^{* * *} \\
(0.36)\end{array}$ \\
\hline ln distance ratio & $\begin{array}{l}-0.57^{* * *} \\
(0.13)\end{array}$ & $\begin{array}{l}-1.11^{* * *} \\
(0.05)\end{array}$ & $\begin{array}{l}-0.85^{* * *} \\
(0.07)\end{array}$ & $\begin{array}{l}-0.83^{* * *} \\
(0.13)\end{array}$ & $\begin{array}{l}-0.84^{* * *} \\
(0.10)\end{array}$ & $\begin{array}{l}-0.93^{* * *} \\
(0.17)\end{array}$ \\
\hline Common border & $\begin{array}{c}-0.39 \\
(0.25)\end{array}$ & $\begin{array}{l}0.49^{* * *} \\
(0.09)\end{array}$ & $\begin{array}{l}0.39 * * \\
(0.16)\end{array}$ & $\begin{array}{r}0.38^{*} \\
(0.22)\end{array}$ & $\begin{array}{l}0.31^{* * *} \\
(0.26)\end{array}$ & $\begin{array}{c}0.13 \\
(0.16)\end{array}$ \\
\hline Common language & $\begin{array}{l}2.03^{* * * *} \\
(0.17)\end{array}$ & $\begin{array}{l}0.96^{* * * *} \\
(0.18)\end{array}$ & $\begin{array}{l}0.79^{* * * *} \\
(0.23)\end{array}$ & $\begin{array}{l}0.81^{* * * *} \\
(0.19)\end{array}$ & $\begin{array}{l}0.92^{* * * *} \\
(0.33)\end{array}$ & $\begin{array}{l}1.02^{* * *} \\
(0.19)\end{array}$ \\
\hline Same country & $\begin{array}{l}2.45^{* * *} \\
(0.20)\end{array}$ & $\begin{array}{l}2.62^{* * *} \\
(0.43)\end{array}$ & & & & \\
\hline $\ln (1+$ tariff $/ 100)$ & & $\begin{array}{l}-8.62^{* * *} \\
(1.46)\end{array}$ & & & & \\
\hline NTB coverage & $\begin{array}{c}-0.63 \\
(0.53)\end{array}$ & $\begin{array}{l}-1.50^{* * *} \\
(0.16)\end{array}$ & & & & \\
\hline Institutions, quality & $\begin{array}{c}0.50 \\
(0.53)\end{array}$ & $\begin{array}{l}4.34^{* * *} \\
(0.73)\end{array}$ & $\begin{array}{l}3.02^{* * *} \\
(0.86)\end{array}$ & $\begin{array}{l}2.18 \\
(2.35)\end{array}$ & $\begin{array}{l}4.34^{* *} \\
(1.80)\end{array}$ & $\begin{array}{c}2.81 \\
(4.19)\end{array}$ \\
\hline Institutions, distance & $\begin{array}{r}-0.39^{*} \\
(0.22)\end{array}$ & $\begin{array}{l}-0.79^{* * *} \\
(0.28)\end{array}$ & $\begin{array}{l}-2.24^{* * *} \\
(0.71)\end{array}$ & $\begin{array}{l}-2.39 * * * \\
(1.15)\end{array}$ & $\begin{array}{c}-1.18 \\
(1.18)\end{array}$ & $\begin{array}{c}-0.22 \\
(1.79)\end{array}$ \\
\hline First-stage regressions & & & & & & \\
\hline Wage: partial $R^{2}$ & 0.088 & 0.765 & 0.414 & 0.414 & 0.536 & 0.536 \\
\hline $\begin{array}{l}\text { Institutions: partial } R^{2} \\
\text { Second-stage regression }\end{array}$ & 0.169 & 0.758 & 0.398 & 0.398 & 0.332 & 0.332 \\
\hline Centred $R^{2}$ & 0.990 & 0.950 & 0.427 & 0.406 & 0.382 & 0.414 \\
\hline RMSE & 0.139 & 0.299 & 0.898 & 0.91 & 0.93 & 0.91 \\
\hline Sargan test & 1.49 & 0.01 & 3.42 & 0.63 & 4.25 & 1.25 \\
\hline$P$-value & 0.22 & 0.91 & 0.06 & 0.43 & 0.04 & 0.26 \\
\hline Wu-Hausman F-test & 0.54 & 8.67 & 32.09 & & 8.81 & \\
\hline$P$-value & 0.58 & 0.00 & 0.00 & & 0.00 & \\
\hline Durbin-Wu-Hausman $\chi^{2}$ test & 1.92 & 29.99 & 57.73 & & 17.10 & \\
\hline$P$-value & 0.38 & 0.00 & 0.00 & & 0.00 & \\
\hline Pagan-Hall test & & 396.01 & 22.73 & & 16.06 & \\
\hline$P$-value & & 0.29 & 0.00 & & 0.01 & \\
\hline No. of observations & 607 & 867 & 494 & 494 & 288 & 288 \\
\hline
\end{tabular}

Note: Standard errors in parentheses. ${ }^{* * *},{ }^{* *}$ and ${ }^{*}$ represent, respectively, statistical significance at the 1,5 and 10 per cent levels, respectively. 
(0.01, $P=0.91)$, testify to the relevance of the chosen instruments. The two endogeneity tests justify the use of an instrumental variables estimator. All coefficients are significant at the 1 per cent level. The coefficient on wage ratio is equal to -1.03 , yielding a more credible value of the elasticity of substitution $\sigma$. Compared to OLS and GLS estimations presented in Table 3, the effect of NTB and the quality of institutions on cross border trade, obtained with IV, is much larger. The impact of import tariffs and institutional quality, on the contrary, is lower with a IV estimator. The elimination of tariffs for European trade, which amount at the beginning of the period to a 5 per cent average, generates according to estimates in column 2, a 43 per cent $=\left[5^{*}(-8.62)\right]$ increase in trade. Opposed to results obtained with OLS and GLS estimators, the effect of the quality of institutions on trade is 5.5 times larger than the effect of the institutional distance separating the countries. Still, in the case of the EBRD, the two measures are not orthogonal: any improvement in the functioning of the institutions of CEE countries reduces the institutional distance separating them from EU members. The results are very similar if the NTB coverage ratio is substituted by the NTB frequency ratio.

In columns $3 a$ and $3 b$, the Kaufmann general index is used to construct the two institutional variables, and in the last two columns we employ the Fraser index. The $\chi^{2}$ score of the Sargan test (equal to 3.42 with the Kaufmann index, and to 4.25 with the Fraser index) is below the 1 per cent critical value, suggesting that the null hypothesis, which states that the selected instruments are appropriate, should be accepted in both cases. The value of the $\mathrm{Wu}$-Hausman test statistic, shown in Table 5 (32.09, and respectively, 8.81), is well above the 1 per cent critical value of the $\chi^{2}$ distribution, indicating that wage and institutions in (17) are truly endogenous variables. IV estimations reveal institutions as stronger determinants of trade. However, for both Kaufmann and Fraser indices, the IV estimator does not correct for heteroscedasticity in the first and second stage estimations. This is reflected in the significant Pagan-Hall statistic, shown at the bottom of Table 5. The generalized method of moments (GMM) estimator is used to fix this problem. Again, the GMM equivalent of the Sargan test, also called the $J$ statistic of Hansen, confirms that the selected instruments are appropriate. Switching to the GMM estimator reduces the statistical significance of the institutional effects. However, we do not consider this loss to be important as we base our main conclusions on the IEF and EBRD index. Results in column 3a, the only one yielding significant estimates for both institutional variables, show that the reduction of the institutional distance separating two countries generates about as much trade as an equal upward shift in the quality of institutions of both countries.

Whenever endogeneity is present, IV and GMM estimates of the wage ratio coefficient are, in absolute value, larger than 1 complying with the predictions of the theoretical model. One concludes that wages can be employed as proxies for factory prices, only if one corrects for the introduced endogeneity. Using either of the four institutional measures described above yields similar results: international trade increases when national institutions work better, and are less different. Trade 
liberalization, translated into lower import tariffs and lower shares of trade subject to NTB, has a strong trade-boosting effect. Nevertheless, as we have seen, the improvement of institutions is expected to increase trade between European partners, suggesting that trade integration can continue even when complete trade liberalization is reached.

\section{Trade policy vs. institutional reforms}

There are two possible ways in which one can make judgements about the relative importance of trade policy instruments and reforms of national institutions for regional trade integration. The first method consists in determining the share of the overall border effect explained by each determinant. The second looks at the volume of additional bilateral trade generated by complete trade liberalization, or by fully accomplished institutional reforms. For both approaches, estimates of imports relative to domestic trade $m_{i j} / m_{j j}$ are used.

The overall border effect between two countries $i$ and $j$ reflects the loss in trade caused by all border-related barriers. I compute this border effect, labelled $B E$, as the exponential of the constant term of Equation (15) taken with opposite sign: $B E$ $=\exp \left((\sigma-1) B_{i j}\right)$. Recall that Equation (15) is obtained from trade specification (14) by dropping all border-specific trade costs and assumes a uniform effect of the quality of national institutions on the trade within and across national borders. If institutions are assumed to matter for cross-border trade alone, in order to estimate the total borderrelated costs one should drop the institutional term from (15). In this case, all institutional variables refer to border-specific costs and are captured by the constant term.

As one cannot know all elements determining trade costs, we adopt an indirect method of finding the share of trade costs corresponding to tariffs and non-tariff barriers on one side, and to worldwide institutional diversity on the other. ${ }^{12}$ The residual border effect, left unexplained by these variables is obtained by introducing separately trade policy and institutional distance in Equation (15):

$$
\begin{gathered}
\ln \frac{m_{i j}}{m_{j j}}=b_{0}+b_{1} \ln \frac{y_{i}}{y_{j}}+b_{2} \ln \frac{w_{i}}{w_{j}}+b_{3} \ln \frac{d_{i j}}{d_{j j}}+b_{4} \ln \left(1+t_{i j}\right)+b_{5} n t b_{i j}+u_{i j} \\
\ln \frac{m_{i j}}{m_{j j}}=c_{0}+c_{1} \ln \frac{y_{i}}{y_{j}}+c_{2} \ln \frac{w_{i}}{w_{j}}+c_{3} \ln \frac{d_{i j}}{d_{j j}}+c_{4} \text { InstitDist }_{i j}+v_{i j} .
\end{gathered}
$$

The amount of border-specific costs, in terms of trade volume explained by trade liberalization and by institutions is then obtained as the difference between

\footnotetext{
${ }^{12}$ Indeed, important border effects are obtained when we include trade policy and institutional variables: Tables 3 and 5 .
} 
Table 6. The relative importance of trade barriers due to tariffs, NTB, and institutional heterogeneity

\begin{tabular}{lcccr}
\hline & $\mathbf{1 9 9 3}$ & $\mathbf{1 9 9 5}$ & $\mathbf{1 9 9 8}$ & $\mathbf{2 0 0 0}$ \\
\hline Institutional measure: IEF & & & & \\
Total border effect & & 45.8 & 35.2 & 23.4 \\
Import tariff and NTB coverage & & 0.62 & 0.45 & 0.26 \\
Institutional distance & & 0.14 & 0.10 & 0.08 \\
Institutional measure: EBRD index & 55.5 & 50.8 & 35.1 & \\
Total border effect & 0.62 & 0.67 & 0.52 & 0.39 \\
Import tariff and NTB coverage & 0.31 & 0.23 & 0.13 & 0.06 \\
Institutional distance & & & \\
\hline
\end{tabular}

Note: Figures in italics represent the average European border effect. The other figures show the share of this border effect explained by each set of variables. The quality of institutions is considered equally important for both foreign and domestic trade, and cannot be held responsible for a lower level of international trade relative to internal shipments.

the overall border effect BE, and the residual border effect estimated by (19) and by (20). Hence, the share of cross-border trade costs explained by each factor is computed as follows:

$$
\begin{array}{ll}
\text { Trade policy: } & B_{T L}=\frac{B E-\exp \left(-b_{0}\right)}{\exp \left(-b_{0}\right)} \\
\text { Institutions: } & B_{I R}=\frac{B E-\exp \left(-c_{0}\right)}{\exp \left(-c_{0}\right)} .
\end{array}
$$

Estimates of $B_{T L}$ and $B_{I R}$, using as measures of the quality of institutions the IEF and EBRD index, are shown for four years of our sample in Table 6. In Table 7 results are provided for the same years, where we also assume that the quality of institutions matters for trade across borders, exclusively or to a higher degree than for domestic trade. The contribution to overall trade costs is calculated according to formulas (21), and estimates of $b_{0}$ and $c_{0}$ are obtained with OLS and year fixed effects. By construction, results should take values between 0 and 1 . This is verified except for IEF in 1995, when the estimate of the coefficient of the 1995 dummy is non-significant.

The first conclusion to be drawn from Tables 6 and 7, is the important trade integration that marked the region during the 1990s. International trade costs, expressed as volumes of lost trade, were reduced by more than a half. By the year 2000, Europeans bought about twice as much from regional foreign partners relative to domestic partners as they did in 1993. Second, trade policy instruments explain the largest part of the cross-border trade costs. In the early 1990s, around 60 per cent 
Table 7. The share of trade policy and institutional barriers in total cross-border trade costs

\begin{tabular}{lcccc}
\hline & $\mathbf{1 9 9 3}$ & $\mathbf{1 9 9 5}$ & $\mathbf{1 9 9 8}$ & $\mathbf{2 0 0 0}$ \\
\hline Total border effect & 57.7 & 52.6 & 36.4 & 25.7 \\
Import tariff and NTB coverage & 0.58 & 0.65 & 0.50 & 0.37 \\
IEF score and distance & & -0.07 & 0.13 & 0.16 \\
EBRD score and distance & 0.34 & 0.26 & 0.16 & 0.09 \\
Kaufmann score and distance & & & 0.04 & 0.03 \\
Fraser score and distance & & 0.16 & & 0.06 \\
\hline
\end{tabular}

Note: Figures show the contribution of trade policy and institutional factors in explaining the European border effect. The quality of institutions is considered to matter exclusively for foreign trade and is a source of border effects.

of these costs were due to import tariffs and NTB. Fourteen per cent of the costs were generated by having GD institutions of uneven quality, and 32 per cent - by the discrepancies in the quality of MT institutions. Obviously, there are aspects captured by both types of institutions. Still, one cannot ignore the greater burden on trade of the quality gap between the market institutions of different countries. Finally, observe that the weight of trade policy instruments and of institutional heterogeneity decreased over time. Summing up individual contributions, we conclude that tariffs, NTB and institutions together explained almost all of borderspecific trade costs at the beginning of the period, but only about half of these costs by the year 2000. This indicates the increasing importance of other trade costs. ${ }^{13}$

Alternatively, the role of the foreign trade policy and domestic institutions in promoting regional trade can be assessed by comparing the volume of trade created by the elimination of tariffs and NTB and the elimination of institutional flaws respectively. Since both trade liberalization and reforms of domestic institutions refer first of all to CEE countries in the sample, we focus on the trade of each of them with its EU partners. The trade creation associated with total trade liberalization between East and West European countries is estimated using Equation (17) and the results are shown in Table 8 . We call trade liberalization complete when all tariffs and non-tariff barriers are eliminated. Because of the low number of observations for which NTB data are available, two samples are studied: (i) a small sample, consisting of observations where both tariff and non-tariff data exist, and (ii) a large sample, combining all observations for which import tariffs are available. Similarly, we compute the amount of trade that would be created by institutional

\footnotetext{
${ }^{13}$ When the share of trade policy and institutions in total border-specific costs is estimated from a single trade equation, only the joint effect of the two factors is obtained. In terms of size, it is slightly superior to the share of tariffs and of NTB in Table 6, but inferior to the sum of the two shares.
} 
Table 8. The CEE-EU trade creation effect of trade liberalization and institutional reforms

\begin{tabular}{lrrrrr}
\hline Source of trade creation & \multicolumn{2}{c}{ Small Sample } & & \multicolumn{2}{c}{ Large Sample } \\
\cline { 2 - 3 } & IEF & EBRD & & IEF & EBRD \\
\hline Trade liberalization & 15.2 & 16.4 & & 76.7 & 53.3 \\
Institutional reforms & 7.1 & 4.1 & & 3.9 & 135.7 \\
Trade liberalization and institutional reforms & 23.4 & 21.2 & & 79.8 & 261.4 \\
\hline
\end{tabular}

Note: Figures show the increase in CEE-EU trade, represented as a percentage of observed flows, associated with different economic policies. Trade liberalization means the elimination of existing import tariffs and NTB in the case of the smaller sample, and the elimination of tariffs alone in the case of the larger sample. Institutional reforms consist in improving the quality of national institutions in CEE countries to reach the average level observed across the $15 \mathrm{EU}$ countries.

reforms which increase the quality of the CEE institutions to the average quality level of the corresponding institutions in the EU countries (as in Table 2). These results are shown in Table 8 for both GD and MT institutions, where all figures are expressed as a percentage of actual trade.

Trade creation, associated with each factor separately, and with all of them jointly, is quite low when smaller sample estimates are employed. However, these values are very large when estimations are carried out on the larger sample. Thus, the removal of import tariffs yields between 53 per cent and 77 per cent increase in actual CEE-EU trade. Additional cross-border trade, due to possible reforms of GD institutions in CEE countries, is barely noticeable. Meanwhile, the amount of trade created by reforms of MT institutions is very large and exceeds the positive effect of trade liberalization. Thus, even after CEE-EU trade has been completely liberalized, the improvement of market institutions in CEE countries can have a consistent trade creation effect. It may bring about as much as 54 per cent $[=(1+135.7 /$ 100) $/(1+53.3 / 100)-1]$ more CEE-EU trade, if post-trade liberalization flows are used as a base. Moreover, the data reveal a large amplification effect when the two reforms are introduced simultaneously. Again, evidence of a large positive role of reforms in market institutions is found.

\section{Distinguishing among institutions}

A country's institutional framework is, however, too diverse and broad to be properly evaluated by a single variable. Therefore, as a next step, it is useful to differentiate the various features of the institutional framework, and to identify the ones that matter the most for cross-border trade flows. 
Firstly, we consider the institutional dimensions corresponding to each componentindex used in the computation of the Index of Economic Freedom, and of the EBRD composite measure. The high correlation of individual institutional measures, shown in Figure 2, and in Tables A3 and A4 of Appendix A, requires that each index be used separately in trade specification (17).

Table 9 presents the coefficients of the variables we are interested in and the summary regression statistics for the IEF component indices. The first part of the table shows the OLS estimates of (17). Values of coefficients, close to those obtained with the average IEF index, are obtained for import tariffs and NTB, while they are rarely significantly different from zero for institutional variables. A high inflation rate (corresponding to a low value of the monetary policy factor) and a large black market cause the highest trade friction. Statistically non-significant coefficients for other IEF factors are the result either of the absence of a corresponding effect on trade or of a high correlation of the variables for institutional quality and institutional distance. Estimations with a single explanatory institutional variable are presented in the lower part of Table 9. Unlike before, the Hausman specification test here falls short of the 5 per cent critical value, justifying the use of the random-effects estimator. Coefficients in column 3 reflect, in this case, the average effect of variables InstitDif $_{i j}$ and InstitDist ${ }_{i j}$. A positive value, obtained for the fiscal burden of the government, capital flows and foreign investments, and the black market, suggests a larger effect of the quality of institutions than of institutional distance. Mutual trade would increase if any of the countries reduce tax rates, restrictions on foreign ownership, or the size of black market. Negative estimates of the coefficients, on the contrary, show the prevalence of the similarity in the quality of institutions. This is the case for government intervention in the economy, for property rights, and for regulation factors. When these aspects are considered, extra trade occurs only if there is a joint effort by the two countries. Countries with a poor but similar level of property rights protection, with a high but similar degree of corruption, and/or with a similar level of restrictions on the creation of new businesses, exchange more with each other than with partners characterized by better functioning institutions.

The effect of MT institutions is displayed in Table 10. Coefficients and regression statistics correspond to the separate introduction of each of the nine factors used in the computation of the EBRD index in Equation (17). Fixed-effects estimations are preferred in this case: the Hausman test of fixed versus random effects specifications is always significant at the 10 per cent level and in seven out of nine cases also at the 5 per cent level. The variation in EBRD indices explains a larger share of the variation in the dependent variable than the variation of IEF factors, and also produces coefficient estimates closer to findings in the literature. Moreover, in this case, coefficients of all variables have expected signs and are significant at the 1 per cent level. A one percentage point fall in the average import tariff produces a 7 per cent to 11 per cent increase in bilateral trade. The NTB coefficient is negative and highly significant for all nine EBRD factors. The reduction of those bilateral trade flows subject to NTB by one percentage point produces a 1 per cent

(c) 2007 The Author Journal compilation (c) 2007 The European Bank for Reconstruction and Development 
Table 9. The role of different institutional dimensions: IEF

\begin{tabular}{|c|c|c|c|c|c|c|}
\hline $\begin{array}{l}\text { Model: OLS with year FE } \\
\text { Institutional dimension }\end{array}$ & Tariff & $\begin{array}{c}\text { NTB } \\
\text { coverage }\end{array}$ & $\begin{array}{l}\text { Instit'l } \\
\text { quality }\end{array}$ & $\begin{array}{c}\text { Instit'1 } \\
\text { distance }\end{array}$ & $R^{2}$ & $\begin{array}{l}\text { No. } \\
\text { obs. }\end{array}$ \\
\hline Fiscal burden of government & $\begin{array}{l}-19.68^{* * *} \\
(3.13)\end{array}$ & $\begin{array}{c}0.03 \\
(1.07)\end{array}$ & $\begin{array}{c}0.39 \\
(0.77)\end{array}$ & $\begin{array}{c}0.39 \\
(0.59)\end{array}$ & 0.724 & 1,073 \\
\hline Government intervention & $\begin{array}{l}-18.81^{* * *} \\
(3.23)\end{array}$ & $\begin{array}{c}0.04 \\
(1.07)\end{array}$ & $\begin{array}{l}-0.26 \\
(0.24)\end{array}$ & $\begin{array}{c}0.23 \\
(0.22)\end{array}$ & 0.726 & 1,073 \\
\hline Monetary policy & $\begin{array}{l}-17.98^{* * *} \\
(3.85)\end{array}$ & $\begin{array}{c}0.05 \\
(1.01)\end{array}$ & $\begin{array}{l}0.54^{* * *} \\
(0.25)\end{array}$ & $\begin{array}{l}-0.82^{* * * *} \\
(0.27)\end{array}$ & 0.736 & 1,073 \\
\hline $\begin{array}{l}\text { Capital flows and } \\
\text { foreign investment }\end{array}$ & $\begin{array}{c}-19.76^{* * *} \\
(3.21)\end{array}$ & $\begin{array}{c}0.11 \\
(1.07)\end{array}$ & $\begin{array}{c}0.26 \\
(0.36)\end{array}$ & $\begin{array}{c}0.26 \\
(0.41)\end{array}$ & 0.723 & 1,073 \\
\hline Banking and finance & $\begin{array}{l}-19.74^{* * *} \\
(3.36)\end{array}$ & $\begin{array}{c}0.07 \\
(1.06)\end{array}$ & $\begin{array}{c}-0.09 \\
(0.35)\end{array}$ & $\begin{array}{l}-0.03 \\
(0.33)\end{array}$ & 0.723 & 1,073 \\
\hline Wages and prices & $\begin{array}{l}-19.58^{* * *} \\
(3.37)\end{array}$ & $\begin{array}{c}0.06 \\
(1.06)\end{array}$ & $\begin{array}{c}0.09 \\
(0.36)\end{array}$ & $\begin{array}{c}-0.01 \\
(0.42)\end{array}$ & 0.723 & 1,073 \\
\hline Property rights & $\begin{array}{l}-19.61^{* * *} \\
(3.32)\end{array}$ & $\begin{array}{c}0.10 \\
(1.04)\end{array}$ & $\begin{array}{c}-0.08 \\
(0.58)\end{array}$ & $\begin{array}{l}-0.07 \\
(0.37)\end{array}$ & 0.723 & 1,073 \\
\hline Regulation & $\begin{array}{l}-19.79^{* * *} \\
(3.33)\end{array}$ & $\begin{array}{c}0.15 \\
(1.13)\end{array}$ & $\begin{array}{c}-0.31 \\
(0.47)\end{array}$ & $\begin{array}{l}0.52 \\
(0.42)\end{array}$ & 0.726 & 1,073 \\
\hline Black market & $\begin{array}{c}-19.49^{* * *} \\
(3.24) \\
\end{array}$ & $\begin{array}{c}0.09 \\
(1.09) \\
\end{array}$ & $\begin{array}{c}0.37 \\
(0.32)\end{array}$ & $\begin{array}{l}-0.68^{* * *} \\
(0.25)\end{array}$ & 0.733 & 1,073 \\
\hline $\begin{array}{l}\text { Model: GLS } \\
\text { Institutional dimension }\end{array}$ & Tariff & $\begin{array}{c}\text { NTB } \\
\text { coverage }\end{array}$ & Instit & & $\begin{array}{c}\text { Hausman } \\
\text { test }\end{array}$ & $\begin{array}{l}\text { No. } \\
\text { obs. }\end{array}$ \\
\hline Fiscal burden of government & $\begin{array}{c}-19.61^{* * *} \\
(0.30)\end{array}$ & $\begin{array}{c}0.12 \\
(0.07)\end{array}$ & $\begin{array}{l}0.23^{* * *} \\
(0.07)\end{array}$ & & $\begin{array}{l}5.14 \\
(0.162)\end{array}$ & 1,073 \\
\hline Government intervention & $\begin{array}{c}-19.06^{* * *} \\
(0.23)\end{array}$ & $\begin{array}{c}0.12 \\
(0.11)\end{array}$ & $\begin{array}{l}-0.17^{* * *} \\
(0.03)\end{array}$ & & $\begin{array}{l}6.47 \\
(0.091)\end{array}$ & 1,073 \\
\hline Monetary policy & $\begin{array}{l}-19.93^{* * *} \\
(0.52)\end{array}$ & $\begin{array}{c}0.05 \\
(0.11)\end{array}$ & $\begin{array}{l}0.35^{* * *} \\
(0.04)\end{array}$ & & $\begin{array}{l}0.14 \\
(0.986)\end{array}$ & 1,073 \\
\hline $\begin{array}{l}\text { Capital flow and } \\
\text { foreign investment }\end{array}$ & $\begin{array}{l}-19.44^{* * *} \\
(0.20)\end{array}$ & $\begin{array}{l}0.09^{* * * *} \\
(0.04)\end{array}$ & $\begin{array}{l}0.52^{* * *} \\
(0.09)\end{array}$ & & $\begin{array}{l}4.37 \\
(0.112)\end{array}$ & 1,073 \\
\hline Banking and finance & $\begin{array}{l}-19.54^{* * *} \\
(0.21)\end{array}$ & $\begin{array}{l}0.19^{* * *} \\
(0.08)\end{array}$ & $\begin{array}{r}-0.05^{*} \\
(0.03)\end{array}$ & & $\begin{array}{l}5.03 \\
(0.170)\end{array}$ & 1,073 \\
\hline Wages and prices & $\begin{array}{l}-19.43^{* * *} \\
(0.24)\end{array}$ & $\begin{array}{l}0.10^{*} \\
(0.06)\end{array}$ & $\begin{array}{c}0.06 \\
(0.04)\end{array}$ & & $\begin{array}{l}6.73 \\
(0.081)\end{array}$ & 1,073 \\
\hline Property rights & $\begin{array}{c}-19.54^{* * *} \\
(0.16)\end{array}$ & $\begin{array}{l}0.24^{* * *} \\
(0.07)\end{array}$ & $\begin{array}{l}-0.12^{* * *} \\
(0.04)\end{array}$ & & $\begin{array}{l}1.97 \\
(0.373)\end{array}$ & 1,073 \\
\hline Regulation & $\begin{array}{l}-18.92^{* * *} \\
(0.25)\end{array}$ & $\begin{array}{l}0.14^{* * *} \\
(0.04)\end{array}$ & $\begin{array}{l}-0.39^{* * *} \\
(0.04)\end{array}$ & & $\begin{array}{l}4.78 \\
(0.189)\end{array}$ & 1,073 \\
\hline Black market & $\begin{array}{c}-19.02^{* * *} \\
(0.37)\end{array}$ & $\begin{array}{c}0.03 \\
(0.08)\end{array}$ & $\begin{array}{l}0.27^{* * *} \\
(0.03)\end{array}$ & & $\begin{array}{l}7.49 \\
(0.058)\end{array}$ & 1,073 \\
\hline
\end{tabular}

Note: Standard errors in parentheses: ${ }^{* * *}, * *$ and ${ }^{*}$ represent, respectively, statistical significance at the 1,5 and 10 per cent levels, respectively. 
Table 10. The role of different institutional dimensions: EBRD index

\begin{tabular}{lccccccc}
\hline Model: FE & Tariff & $\begin{array}{c}\text { NTB } \\
\text { coverage }\end{array}$ & $\begin{array}{c}\text { Instit'1 } \\
\text { quality }\end{array}$ & $\begin{array}{c}\text { Instit'l } \\
\text { distance }\end{array}$ & $\begin{array}{c}R^{2} \\
\text { Hausman } \\
\text { test }\end{array}$ & $\begin{array}{c}\text { No. of } \\
\text { observations }\end{array}$ \\
\hline Price liberalization & $-10.81^{* * * *}$ & $-1.12^{* * *}$ & $2.72^{* * *}$ & $-1.98^{* * *}$ & 0.785 & 25.073 & 1,356 \\
& $(1.33)$ & $(0.17)$ & $(0.43)$ & $(0.30)$ & $(0.005)$ & \\
Foreign exchange and & $-7.08^{* * *}$ & $-0.85^{* * *}$ & $2.44^{* * *}$ & $-3.89^{* * *}$ & 0.792 & 28.450 & 1,356 \\
trade liberalization & $(1.32)$ & $(0.17)$ & $(0.97)$ & $(0.92)$ & & $(0.002)$ & \\
Small-scale & $-9.47^{* * *}$ & $-1.27^{* * *}$ & $2.11^{* * *}$ & $-0.96^{* * *}$ & 0.788 & 21.179 & 1,356 \\
privatization & $(1.26)$ & $(0.20)$ & $(0.35)$ & $(0.34)$ & & $(0.020)$ & \\
Large-scale & $-8.62^{* * *}$ & $-0.99^{* * *}$ & $2.28^{* * *}$ & $-1.49^{* * *}$ & 0.795 & 17.119 & 1,356 \\
privatization & $(1.51)$ & $(0.16)$ & $(0.27)$ & $(0.29)$ & & $(0.072)$ & \\
Enterprise reform & $-9.49^{* * *}$ & $-0.97^{* * *}$ & $1.28^{* * *}$ & $-1.14^{* * *}$ & 0.785 & 21.057 & 1,356 \\
& $(1.48)$ & $(0.17)$ & $(0.24)$ & $(0.21)$ & & $(0.021)$ & \\
Competition policy & $-11.92^{* * *}$ & $-1.21^{* * *}$ & $2.20^{* * *}$ & $-0.75^{* * *}$ & 0.794 & 24.506 & 1,356 \\
& $(1.36)$ & $(0.16)$ & $(0.24)$ & $(0.17)$ & & $(0.006)$ & \\
Infrastructure reform & $-8.94^{* * *}$ & $-1.00^{* * *}$ & $1.61^{* * *}$ & $-1.12^{* * *}$ & 0.790 & 19.018 & 1,356 \\
& $(1.33)$ & $(0.16)$ & $(0.24)$ & $(0.18)$ & & $(0.040)$ & \\
Banking sector & $-7.85^{* * *}$ & $-1.10^{* * *}$ & $1.84^{* * *}$ & $-1.37^{* * *}$ & 0.793 & 18.777 & 1,356 \\
& $(1.40)$ & $(0.16)$ & $(0.30)$ & $(0.26)$ & & $(0.043)$ & \\
Non-banking financial & $-9.81^{* * *}$ & $-1.13^{* * *}$ & $1.69^{* * *}$ & $-0.93^{* * *}$ & 0.793 & 17.464 & 1,356 \\
institutions & $(1.35)$ & $(0.16)$ & $(0.22)$ & $(0.17)$ & & $(0.065)$ & \\
\hline
\end{tabular}

Note: Standard errors in parentheses: ${ }^{* * *}{ }^{* *}$ and ${ }^{*}$ represent, respectively, statistical significance at the 1, 5 and 10 per cent levels, respectively.

rise in trade. European trade integration will benefit both from better performing and more similar market institutions. This fact is verified by each component of the EBRD index. Still, the effect is more prominent for increased liberalization of markets, for privatization, and for strong domestic competition.

Despite the improved knowledge about the role of specific institutions, provided by results presented in Tables 9 and 10, it is difficult to formulate rigorous economic policy recommendations on the basis of qualitative (index) variables. What exactly is the meaning of a re-scaled score of 0.5 of the IEF or EBRD index, or of any of their component factors? What does a ten point increase in this value correspond to and how specifically can it be achieved by an economy? Government officials operate with very precise measures, and a more quantified view of institutions is necessary to satisfy their needs.

In the rest of this section we concentrate on CEE exports to the EU, the trade flows with the highest growth potential within the region. Conclusions formulated 
below can serve as guidelines for governments of CEE countries in undertaking those reforms with the strongest potential positive impact on their export performance in West European markets.

All results obtained with index measures of the quality of institutions emphasize the important role of MT institutions in the trade between the selected European countries. Therefore, we focus below on quantitative variables characterizing this type of institution. We assume that compared to CEE countries, all EU members have wellfunctioning market institutions, and their improvement is ruled out. This restriction is consistent with the economic policy approach: CEE governments can at most produce changes in their domestic institutions. Hence, one can ignore the quality of institutions in EU countries and derive an adequate trade specification for CEE exports to EU:

$$
\begin{aligned}
\ln \frac{m_{i j}}{m_{j j}}= & \alpha_{0}+\alpha_{1} \ln \frac{y_{i}}{y_{j}}+\alpha_{2} \ln \frac{w_{i}}{w_{j}}+\alpha_{3} \ln \frac{d_{i j}}{d_{j j}}+\alpha_{4} \text { border }_{i j}+\alpha_{5} \text { lang }_{i j} \\
& +\alpha_{6} \text { country } y_{i j}+\alpha_{7} \ln (1+\text { tariff. })+\alpha_{8} n t b_{i j}+\alpha_{9} \text { Instit }_{i}+\omega_{i j} .
\end{aligned}
$$

A single institutional variable reflecting the quality of market institutions in the exporting CEE country $i$, Instit ${ }_{i}$, is included. Institutional distance is dropped because of collinearity with the variable Instit. Indeed, any change in the functioning of institutions in $i$ translates immediately into a corresponding shift in the institutional distance with respect to any importing EU country $j$.

Eleven different continuous variables are used to portray CEE's market institutions, and the estimated coefficients of (22) are presented in the first column of Table 11. They are highly significant, except the average bribe tax. Average values of institutional variables across CEE countries are also indicated. The impact of each aspect of the institutional framework of the CEE countries on their exports to the EU is computed for one unit and one standard deviation unit change in institutional variables, and is displayed in the last two columns of Table 11.

The private sector accounts for about 62 per cent of CEE economies. One percentage point increase of that share will generate a 1.57 per cent growth of CEE exports to EU. The largest effect is observed for budget subsidies and bribes. One percentage point change in the share of budgetary subsidies and of firms giving bribes reduces CEE exports by 2.89 per cent and 2.18 per cent, respectively. Similarly, an increased number of non-performing loans reduces the exporting performance of the country. On the contrary, the presence of foreign-owned banks, as well as the increased competition in the banking sector (associated with its fragmentation), results in greater access of well-performing exporting firms to funds, and increases the trust of EU partners in the respect for contract stipulations. Not surprisingly, the private sector is a leading factor for exports. Its expansion, both in terms of production and employed labour force, together with increased access to credit for private firms, are an important precondition for the growth of CEE exports. Another important determinant is the investment rate in the economy. During the 1990s, it amounted 
Table 11. The role of MT institutions for CEE exports to EU

\begin{tabular}{|c|c|c|c|c|c|c|}
\hline \multirow{2}{*}{$\begin{array}{l}\text { Model: OLS } \\
\text { Institutional dimension }\end{array}$} & \multirow[t]{2}{*}{ Instit coeff } & \multirow[t]{2}{*}{$R^{2}$} & \multirow{2}{*}{$\begin{array}{c}\text { No. of } \\
\text { observations }\end{array}$} & \multirow[t]{2}{*}{ Mean (SD) } & \multicolumn{2}{|c|}{ Effect on tradet } \\
\hline & & & & & $\Delta=\mathrm{SD}$ & $\Delta=1$ \\
\hline invale sector in & $0.04^{* * *}(0.01)$ & 0.826 & 64 & $62.13(11.93)$ & 4.55 & 1.57 \\
\hline $\begin{array}{c}\text { Private sector in } \\
\text { employment }\end{array}$ & $0.02^{* * *}(0.01)$ & 0.777 & 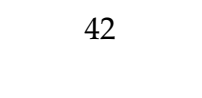 & $59.83(13.01)$ & 1.67 & 0.58 \\
\hline Budgetary subsidies & $-0.08^{* * *}(0.02)$ & 0.805 & 62 & $4.15(4.48)$ & -8.03 & -2.89 \\
\hline Investment rate & $0.05^{* * *}(0.02)$ & 0.806 & 64 & $24.28(6.44)$ & 5.33 & 1.84 \\
\hline Number of banks & $0.01^{* * *}(0.01)$ & 0.791 & 64 & 36.58 (19.18) & 0.64 & 0.22 \\
\hline Foreign-owned banks & $0.03^{* * *}(0.01)$ & 0.799 & 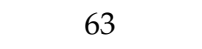 & $13.54(10.35)$ & 3.29 & 1.14 \\
\hline Non-performing loans & $-0.02^{* * *}(0.01)$ & 0.832 & 53 & $17.88(13.47)$ & -1.81 & -0.64 \\
\hline $\begin{array}{l}\text { Domestic credit to } \\
\text { private sector }\end{array}$ & $0.05^{* * *}(0.01)$ & 0.852 & 63 & $22.02(12.68)$ & 5.24 & 1.81 \\
\hline Broad money M2 & $0.02^{* * *}(0.01)$ & 0.826 & 64 & 42.55 (18.05) & 2.41 & 0.84 \\
\hline $\begin{array}{l}\text { Firms giving bribes } \\
\text { frequently }(\%)\end{array}$ & $-0.06^{* * *}(0.01)$ & 0.826 & 24 & $26.48(11.45)$ & -6.10 & -2.18 \\
\hline Average bribe tax & $1.07(1.28)$ & 0.834 & 24 & $1.24(0.35)$ & ns & ns \\
\hline
\end{tabular}

Note: Standard errors in parentheses. ${ }^{* * *},{ }^{* *}$ and ${ }^{*}$ represent, respectively, statistical significance at the 1,5 and 10 per cent levels; + Effects on trade are percentage changes in relative imports, caused by one unit increase and one standard deviation increase respectively, in the value of the institutional variable.

to 24 per cent of the CEE domestic product. Raising this figure by one percentage point will produce a 1.84 per cent growth of exports to the EU.

Hence, a CEE country, eager to increase its exports to the EU market, should start by reducing budgetary subsidies and corruption, and should privilege the development of private sector and domestic investment. Banking sector and monetary policy issues, although important, lead to less important gains.

\section{Conclusion}

Trade policy and national institutions are two important determinants of cross-border trade flows. We use a simple monopolistic trade model, with a trade costs structure that includes tariffs, non-tariff barriers, and institutions, to investigate the role of these factors. Our model and data show that national institutions, measured both in terms of quality and similarity, along with instruments of foreign trade policy, have a strong and significant impact on trade between European countries. This result is confirmed by the use of both index, and continuous variables, as measures for the quality of institutions. Still, the magnitude of the effect on trade is smaller for 
institutions associated with the general development of the economy, and larger for institutions specific to transition economies. Reverse causality between trade and institutions is also considered and evidence is found that larger trade volumes stimulate reforms of the institutional framework. The role of trade liberalization in promoting regional trade integration is compared to that of institutional reforms employing two different methods. Both of them compute the part of total borderspecific trade costs explained by each factor and determine the size of the additional trade created by complete CEE-EU trade liberalization, and by possible reforms of domestic institutions. The results obtained with the two methods point out the nonnegligible contribution of institutional reforms of regional trade. In addition, both approaches ascribe the major role to the improvement of market institutions in CEE countries. A further increase in CEE-EU trade, comparable in size to the that due to trade liberalization, is possible, even after all policy barriers to trade have been removed. Data also suggest that regional trade is most sensitive to restrictions on international trade flow and foreign investment and least to government controls on wages and prices. Finally, the use of quantitative institutional measures allows us to formulate specific policy recommendations for increasing CEE exports to the EU market. Corruption and large budgetary subsidies are the highest impediments to CEE products reaching EU markets, while the level of concentration in the banking sector, as well as the participation of the private sector in employment, are of marginal importance.

\section{References}

Acemoglu, D., Robinson, J. A. and Johnson, S. (2001). 'The colonial origins of comparative development: An empirical investigation', American Economic Review, 91(5), pp. 1369-401.

Anderson, J. E. and Marcouiller, D. (2002). 'Insecurity and the pattern of trade: An empirical investigation', Review of Economics and Statistics, 84(2), pp. 342-52.

Anderson, J. E. and Young, L. (2002). 'Imperfect contract enforcement', NBER Working Papers 8847. Cambridge, MA: National Bureau of Economic Research.

Baldwin, R. (1993). 'The potential for trade between the countries of EFTA and Central and Eastern Europe', CEPR Discussion Paper 853, London: Centre for Economic Policy Research.

Bouët, A., Fontagné, L., Mimouni, M. and Pichot, X. (2001). 'Market access maps: A bilateral and dissaggregated measure of market access', CEPII Working Paper 18, Paris: CEPII.

Coase, R. (1937). 'The nature of the firm', Economica, 4, pp. 386-406.

de Groot, H., Linders, G.-J., Rietveld, P. and Subramanian, U. (2004). 'The institutional determinants of bilateral trade patterns', Kyklos, 57(1), pp. 103-24.

Dixit, A. K. and Stiglitz, J. E. (1977). 'Monopolistic competition and optimal product diversity', American Economic Review, 67(3), pp. 297-308.

Duc, C., Granger, C., Lavallé, E. and Siroën, J.-M. (2005). 'Echange et contraintes institutionnelles dans les relations de l'Union Européenne avec les pays de sa périphérie', EURIsCO Working Paper, Paris: Centre de Recherche en Économie.

Easterly, W. and Levine, R. (2003). 'Tropics, germs, and crops: How endowments influence economic development', NBER Discussion Paper 9106. Cambridge, MA: National Bureau of Economic Research. 
Fontagné, L., Freudenberg, M. and Pajot, M. (1999). 'Le potentiel d'échanges entre l'Union européenne et les PECO', Revue Economique, 50(6), pp. 1139-68.

Frankel, J. A. and Romer, D. (1999). 'Does trade cause growth?' American Economic Review, 89(3), pp. 379-99.

Gros, D. and Gonciarz, A. (1996). 'A note on the trading potential of Central and Eastern Europe', European Journal of Political Economy, 12(4), pp. 709-21.

Hamilton, C. B. and Winters, L. A. (1992). 'Opening up international trade with Eastern Europe', Stockholm - International Economic Studies, 511.

Harrigan, J. (2003). 'Specialisation and the volume of trade: Do the data obey the laws?' in: Kwan Choi, E. and Harrigan, J. (eds.) The Handbook of International Trade. Oxford: Blackwell Publishing, pp. 85-118.

Head, K. and Mayer, T. (2000). 'Non-Europe: The magnitude and causes of market fragmentation in EU', Weltwirtschaftliches Archiv, 136(2), pp. 285-314.

Helliwell, J. F. and Verdier, G. (2001). 'Measuring internal trade distances: A new method applied to estimate provincial border effects in Canada', Canadian Journal of Economics, 34(4), pp. 1024-41.

Jansen, M. and Nordas, H. K. (2004). 'Institutions, trade policy and trade flows', CEPR Discussion Paper 4418. London: Centre for Economic Policy Research.

Kaufmann, D., Kraay, A. and Matruzzi, M. (1999). 'Governance matters', World Bank Policy Research Working Paper 2196. Washington D.C.: The World Bank.

Kaufmann, D., Kraay, A. and Matruzzi, M. (2003). 'Governance matters III: Governance indicators for 1996-2002', World Bank Policy Research Working Paper 3106. Washington D.C.: The World Bank.

Koukhartchouk, O. and Maurel, M. (2003). 'Accession to the WTO and EU enlargement: What potential for trade increase?' CEPR Discussion Paper 3944. London: Centre for Economic Policy Research.

Krugman, P. (1980). 'Scale economies, product differentiation and the pattern of trade', American Economic Review, 70(5), pp. 950-9.

McCallum, J. (1995). 'National borders matter: Canada-US regional trade patterns', American Economic Review, 85(3), pp. 615-23.

North, D. C. (1990). Institutions, Institutional Change and Economic Performance (Political Economy of Institutions and Decisions). Cambridge: Cambridge University Press.

Rodrik, D., Subramanian, A. and Trebbi, F. (2002). 'Institutions rule: The primacy of institutions over geography and integration in economic development', CEPR Discussion Paper 3643. London: Centre for Economic Policy Research.

Trefler, D. (1995). 'The case of missing trade and other mysteries', Journal of International Economics, 85(5), pp. 1029-46.

Turrini, A. and Ypersele, T. V. (2002). 'Traders, courts and the home bias puzzle', CEPR Discussion Paper 3228. London: Centre for Economic Policy Research.

Wang, Z. K. and Winters, L. (1991). 'The trading potential of Eastern Europe', CEPR Discussion Paper 610. London: Centre for Economic Policy Research.

Warner, A. and Sachs, J. (1995). 'Economic reform and the process of global integration', Brookings Papers on Economic Activity, 1, pp. 1-118.

Wei, S.-J. (1996). 'Intranational versus international trade: How stubborn are nations in global integration', NBER Working Paper 5531. Cambridge, MA: National Bureau of Economic Research.

Williamson, O. (2000). 'The new institutional economics: Taking stock, looking ahead', Journal of Economic Literature, 38(3), pp. 595-613.

(c) 2007 The Author Journal compilation @ 2007 The European Bank for Reconstruction and Development 


\section{Appendix A}

\section{Institutional variables}

The Index of Economic Freedom computed by the Heritage Foundation consists of ten institutional measures, evaluating the level of economic freedom in as many different dimensions. The European Bank for Reconstruction and Development has elaborated nine institutional measures to evaluate economic reforms in transition countries. These are published annually in the Bank's Transition Report and are listed in Table A1.

According to the Heritage Foundation, among EU countries, the United Kingdom and Ireland have the most liberalized economies, and Spain and Greece are the least liberalized. Among CEE countries the Czech Republic and Estonia take the lead, with Bulgaria and Romania at the bottom of the list. The former two economies were characterized in 2001 by a level of economic freedom comparable to that of France. From the point of view of undertaken economic reforms, i.e., EBRD index score, Hungary shows the best performance, while Romania has the worst score of the sample. Hence, the well-functioning Czech and Estonian institutions at the beginning of the 21st century are at least partially due to the inheritance of a relatively good institutional framework. (Fig. A1)

Figure A1. Evolution of the institutional framework of CEE countries
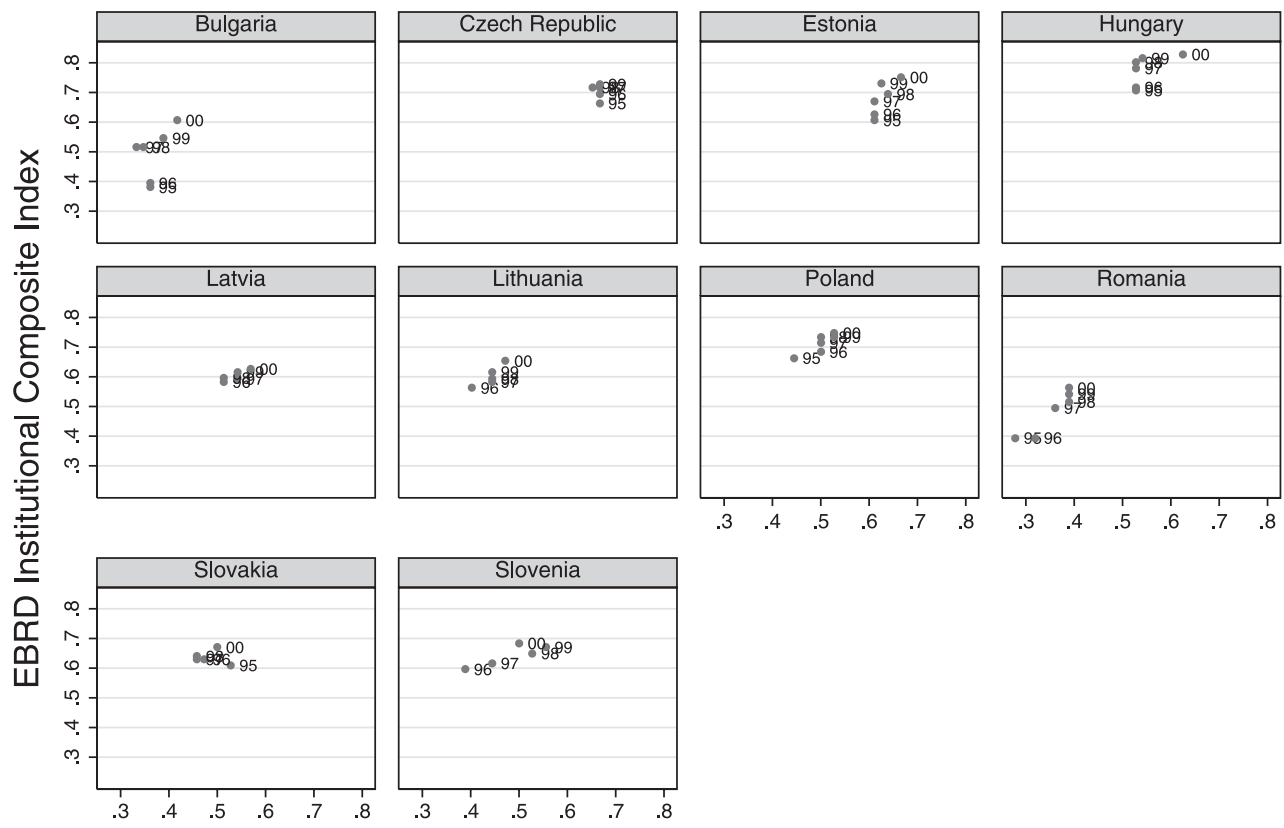

Graphs by country

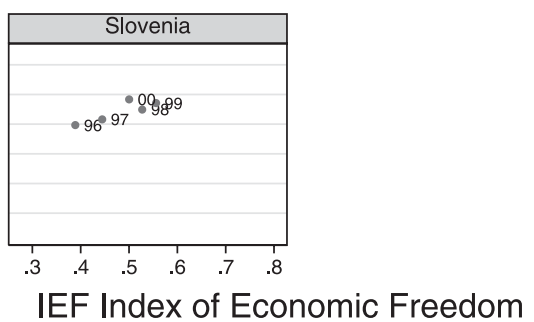


Table A1. Description of institutional and trade policy variables

Variable

No. of

Mean SD Minimum Maximum observations

\begin{tabular}{lrrrrr}
\hline Institutional variables & & & & & \\
\hline Index of Economic Freedom & 135 & 0.60 & 0.12 & 0.28 & 0.81 \\
Trade policy & 135 & 0.69 & 0.20 & 0.25 & 1.00 \\
Fiscal burden of government & 135 & 0.17 & 0.12 & 0.00 & 0.63 \\
Government intervention & 135 & 0.62 & 0.19 & 0.00 & 0.88 \\
Monetary policy & 135 & 0.58 & 0.42 & 0.00 & 1.00 \\
Capital flow and foreign investment & 135 & 0.73 & 0.11 & 0.25 & 1.00 \\
Banking and finance & 135 & 0.66 & 0.20 & 0.25 & 1.00 \\
Wages and prices & 135 & 0.66 & 0.14 & 0.50 & 1.00 \\
Property rights & 135 & 0.76 & 0.21 & 0.25 & 1.00 \\
Regulation & 135 & 0.56 & 0.17 & 0.25 & 1.00 \\
Black market & 135 & 0.69 & 0.28 & 0.00 & 1.00 \\
EBRD index & 192 & 0.83 & 0.22 & 0.24 & 1.00 \\
Price liberalization & 192 & 0.84 & 0.20 & 0.30 & 1.00 \\
Foreign exchange and trade liberalization & 192 & 0.97 & 0.08 & 0.61 & 1.00 \\
Small-scale privatization & 192 & 0.94 & 0.14 & 0.21 & 1.00 \\
Large-scale privatization & 192 & 0.85 & 0.22 & 0.30 & 1.00 \\
Enterprise reform & 192 & 0.79 & 0.26 & 0.00 & 1.00 \\
Competition policy & 192 & 0.76 & 0.30 & 0.00 & 1.00 \\
Infrastructure reform & 192 & 0.74 & 0.34 & 0.00 & 1.00 \\
Banking sector & 192 & 0.83 & 0.23 & 0.00 & 1.00 \\
Non-banking financial institutions & 192 & 0.76 & 0.31 & 0.00 & 1.00 \\
Kaufmann index & 72 & 0.71 & 0.12 & 0.46 & 0.89 \\
Fraser index & 48 & 0.63 & 0.12 & 0.31 & 0.82 \\
Trade policy variables & & & & & \\
Import tariff & 3,126 & 2.34 & 3.24 & 0.00 & 17.12 \\
NTB coverage & 0.24 & 0.24 & 0.00 & 0.97 \\
NTB frequency & 2.34 & 3.24 & 0.00 & 17.12 \\
\hline & & & & & \\
\hline
\end{tabular}


Table A2. Correlation of institutional and trade policy variables

\begin{tabular}{lrrccccc}
\hline Variable & $\begin{array}{c}\text { IEF } \\
\text { index }\end{array}$ & $\begin{array}{c}\text { EBRD } \\
\text { index }\end{array}$ & $\begin{array}{c}\text { Kaufmann } \\
\text { index }\end{array}$ & $\begin{array}{c}\text { Fraser } \\
\text { index }\end{array}$ & $\begin{array}{c}\text { Import } \\
\text { tariff }\end{array}$ & $\begin{array}{c}\text { NTB } \\
\text { coverage }\end{array}$ & $\begin{array}{c}\text { NTB } \\
\text { frequency }\end{array}$ \\
\hline IEF index & 1.00 & & & & & & \\
EBRD index & 0.80 & 1.00 & & & & & \\
Kaufmann index & 0.87 & 0.87 & 1.00 & & & & \\
Fraser index & 0.88 & 0.88 & 0.89 & 1.00 & & & \\
Import tariff & -0.42 & -0.57 & -0.51 & -0.65 & 1.00 & & \\
NTB coverage & -0.16 & -0.09 & & & 0.30 & 1.00 & \\
NTB frequency & 0.06 & -0.08 & & & 0.42 & 0.84 & 1.00 \\
\hline
\end{tabular}


Table A3. Correlation of IEF component indices

\begin{tabular}{|c|c|c|c|c|c|c|c|c|c|c|}
\hline Variables & $\begin{array}{l}\text { Trade } \\
\text { policy }\end{array}$ & $\begin{array}{c}\text { Fiscal } \\
\text { burden of } \\
\text { government }\end{array}$ & $\begin{array}{l}\text { Government } \\
\text { intervention }\end{array}$ & $\begin{array}{c}\text { Monetary } \\
\text { policy }\end{array}$ & $\begin{array}{c}\text { Capital } \\
\text { flow and } \\
\text { foreign } \\
\text { investment }\end{array}$ & $\begin{array}{c}\text { Banking } \\
\text { and } \\
\text { finance }\end{array}$ & $\begin{array}{c}\text { Wages } \\
\text { and } \\
\text { prices }\end{array}$ & $\begin{array}{l}\text { Property } \\
\text { rights }\end{array}$ & Regulation & $\begin{array}{c}\text { Black } \\
\text { market }\end{array}$ \\
\hline Trade policy & 1.00 & & & & & & & & & \\
\hline $\begin{array}{l}\text { Fiscal burden of } \\
\text { government }\end{array}$ & -0.16 & 1.00 & & & & & & & & \\
\hline $\begin{array}{l}\text { Government } \\
\text { intervention }\end{array}$ & 0.12 & 0.16 & 1.00 & & & & & & & \\
\hline Monetary policy & 0.37 & -0.31 & 0.03 & 1.00 & & & & & & \\
\hline $\begin{array}{l}\text { Capital flow and } \\
\text { foreign investment }\end{array}$ & 0.36 & 0.00 & 0.04 & -0.06 & 1.00 & & & & & \\
\hline Banking and finance & 0.16 & -0.04 & 0.09 & 0.29 & 0.25 & 1.00 & & & & \\
\hline Wages and prices & 0.24 & -0.14 & -0.21 & 0.26 & 0.38 & 0.46 & 1.00 & & & \\
\hline Property rights & 0.26 & -0.13 & 0.20 & 0.74 & 0.26 & 0.44 & 0.35 & 1.00 & & \\
\hline Regulation & 0.33 & 0.23 & 0.22 & 0.27 & 0.15 & 0.49 & 0.33 & 0.46 & 1.00 & \\
\hline Black market & 0.24 & -0.34 & 0.06 & 0.78 & 0.06 & 0.32 & 0.25 & 0.75 & 0.23 & 1.00 \\
\hline
\end{tabular}


Table A4. Correlation of EBRD component indices

\begin{tabular}{|c|c|c|c|c|c|c|c|c|c|}
\hline Variable & $\begin{array}{c}\text { Price } \\
\text { liberali- } \\
\text { zation }\end{array}$ & $\begin{array}{c}\text { Foreign } \\
\text { exchange } \\
\text { and trade } \\
\text { liberali- } \\
\text { zation }\end{array}$ & $\begin{array}{l}\text { Small- } \\
\text { scale } \\
\text { privati- } \\
\text { zation }\end{array}$ & $\begin{array}{c}\text { Large- } \\
\text { scale } \\
\text { privati- } \\
\text { zation }\end{array}$ & $\begin{array}{l}\text { Enterprise } \\
\text { reform }\end{array}$ & $\begin{array}{l}\text { Competition } \\
\text { policy }\end{array}$ & $\begin{array}{l}\text { Infras- } \\
\text { tructure } \\
\text { reform }\end{array}$ & $\begin{array}{l}\text { Banking } \\
\text { sector }\end{array}$ & $\begin{array}{c}\text { Non- } \\
\text { banking } \\
\text { financial } \\
\text { institutions }\end{array}$ \\
\hline Price liberalization & 1.00 & & & & & & & & \\
\hline $\begin{array}{c}\text { Foreign exchange and } \\
\text { trade liberalization }\end{array}$ & 0.54 & 1.00 & & & & & & & \\
\hline Small-scale privatization & 0.54 & 0.73 & 1.00 & & & & & & \\
\hline Large-scale privatization & 0.82 & 0.67 & 0.72 & 1.00 & & & & & \\
\hline Enterprise reform & 0.94 & 0.64 & 0.68 & 0.89 & 1.00 & & & & \\
\hline Competition policy & 0.94 & 0.65 & 0.65 & 0.88 & 0.96 & 1.00 & & & \\
\hline Infrastructure reform & 0.93 & 0.67 & 0.65 & 0.87 & 0.94 & 0.94 & 1.00 & & \\
\hline Banking sector & 0.93 & 0.66 & 0.70 & 0.87 & 0.95 & 0.92 & 0.95 & 1.00 & \\
\hline $\begin{array}{l}\text { Non-banking } \\
\text { financial institutions }\end{array}$ & 0.93 & 0.68 & 0.69 & 0.88 & 0.96 & 0.95 & 0.95 & 0.96 & 1.00 \\
\hline
\end{tabular}

